\title{
ANÁLISE DA EXPRESSÃO DO FATOR DE TRANSCRIÇÃO Sf-1 E SUA REGULAÇÃO EM CULTURAS PRIMÁRIAS DE ADRENAL DE RATO: O PAPEL DE Pod-1/TCF21
}

Dissertação apresentada ao Programa de PósGraduação em Ciências Morfofuncionais do Instituto de Ciências Biomédicas da Universidade de São Paulo, para obtenção do Título de Mestre em Ciências. 


\section{ANÁLISE DA EXPRESSÃO DO FATOR DE TRANSCRIÇÃO Sf-1 E SUA REGULAÇÃO EM CULTURAS PRIMÁRIAS DE ADRENAL DE RATO: O PAPEL DE Pod-1/TCF21}

Dissertação apresentada ao Programa de PósGraduação em Ciências Morfofuncionais do Instituto de Ciências Biomédicas da Universidade de São Paulo, para obtenção do Título de Mestre em Ciências.

Área de Concentração: Ciências Morfofuncionais

Orientadora: Profa. Dra. Claudimara Lotfi

Versão corrigida. A versão original eletrônica encontra-se disponível tanto na Biblioteca do ICB quanto na Biblioteca Digital de Teses e Dissertações da USP (BDTD). 
DADOS DE CATALOGAÇÃO NA PUBLICAÇÃO (CIP)

Serviço de Biblioteca e Informação Biomédica do

Instituto de Ciências Biomédicas da Universidade de São Paulo

(c) reprodução total

Abreu, Nayara Pereira de.

Análise da expressão do fator de transcrição $S f-1$ e sua regulação em culturas primárias de adrenal de rato: o papel de Pod-1/TCF21 /

Nayara Pereira de Abreu. -- São Paulo, 2013.

Orientador: Profa. Dra. Claudimara Ferini Pacicco Lofti.

Dissertação (Mestrado) - Universidade de São Paulo. Instituto de Ciências Biomédicas. Departamento de Anatomia. Área de concentração: Ciências Morfofuncionais. Linha de pesquisa: Estudos in vivo e in vitro da sinalização, expressão gênica e proliferação de células normais e tumorais da suprarrenal.

Versão do título para o inglês: Analysis of Sf-1 transcription factor and its regulation in rat adrenal cell primary culture: the role of Pod-1/TCF21.

$\begin{array}{lll}\text { 1. Suprarrenal 2. Cultura de células primárias de rato } 3 \text {. Células } & \end{array}$ glomerulosas 4. Células fasciculadas 5 . Células reticulares 6 . Sf-1 I. Lofti, Profa. Dra. Claudimara Ferini Pacicco II. Universidade de São Paulo. Instituto de Ciências Biomédicas. Programa de Pós-Graduação em Ciências Morfofuncionais III. Título. 
Título da

Análise da expressão do fator de transcrição Sf-1 e sua regulação em culturas primárias de adrenal de rato: o papel de Pod-1/TCF21.

Orientador(a):

Profa. Dra. Claudimara Ferini Pacicco Lofti.

A Comissão Julgadora dos trabalhos de Defesa da Dissertação de Mestrado, em sessão pública realizada a considerou
( ) Aprovado(a)
( ) Reprovado(a)

Examinador(a): Assinatura:

Nome:

Instituição:

Examinador(a): Assinatura:

Nome:

Instituição:

Presidente: Assinatura:

Nome:

Instituição: 


\section{Certificado}

Certificamos que o protocolo registrado sob $n^{\circ} 031$ nas fls. 101 do livro 02 para uso de animais em experimentação, sob a responsabilidade do Prof(a) Dr(a)) Claudimara Ferini Pacicco Lotfi, Coordenador(a) da Linha de pesquisa "Estudo da expressão do fator de transcrição SF-1 e sua regulação em culturas primárias de adrenal de rato: o papel de Pod-1/TCF-21" do qual participam o(s) alunos Nayara Pereira de Abreu, está de acordo com os Princípios Éticos de Experimentação Animal adotado pela Sociedade Brasileira de Ciência de Animais de Laboratório (SBCAL) e foi aprovado pela COMISSÃO DE ÉTICA NO USO DE ANIMAIS (CEUA) em 01.04.2011, com validade de 3 anos.

São Paulo, 01 de abril de 2011.
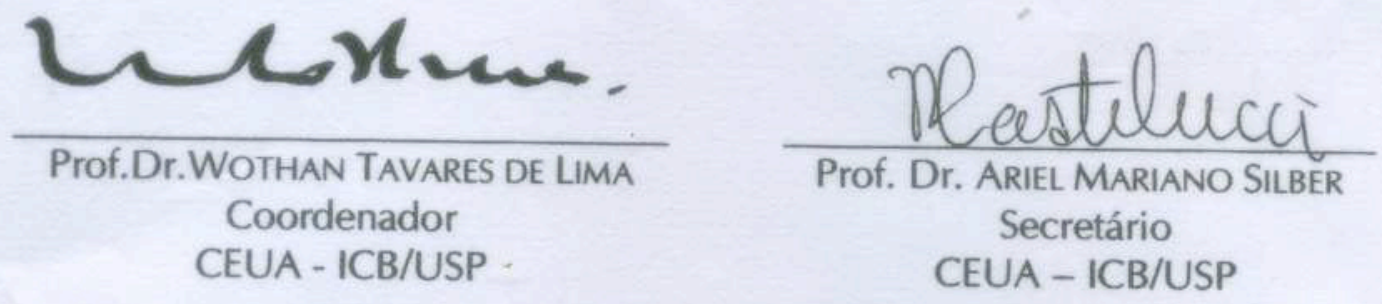
Aos meus pais, João Horlando Abreu e Marinalva, Abreu que são minha razão de viver e sempre me apoiaram e acreditaram que chegaria até aqui.

Obrigado! 


\section{AGRADECIMENTOS}

A Deus.

Aos meus pais, João Horlando Abreu e Marinalva Abreu, e aos meus familiares por todo apoio e confiança.

À minha orientadora, Dra. Claudimara Lotfi, pela oportunidade e por sua infinita paciência.

Aos meus colegas de laboratório, por me aturarem durante esses dois anos, em especial a Dra. Gabriele Mattos, à doutoranda Mônica França e ao Dr. Pedro Mendonça, por todos os ensinamentos.

À técnica Joelcimar Martins, por sempre me ajudar nos momentos difíceis, tanto acadêmicos quanto pessoais.

A todos os meus amigos da Unirg, da república e do prédio "Bob Esponja", que fizeram parte dessa caminhada. Em especial, a Alan, a Joelcy, a Maria Joana, a Lorena, a Alcides, a Kaio, a Haila, a Ana, a Cindy, a Andrés, a Pedro, a Gabriel e a Laura.

À Profa. Dra. Maria Luiza Morais Barreto de Chaves, por permitir o uso dos equipamentos em seu laboratório e a seus alunos de pós-graduação, por ajudarem em seu manuseio.

À técnica Marta do laboratório de histologia, por toda paciência em me ensinar.

A todos os funcionários do corpo técnico do biotério.

Aos funcionários da secretaria.

Aos auxiliares de serviços gerais e aos vigilantes.

Às agências de fomento CAPES, CNPQ e FAPESP. 
“A tarefa não é tanto ver aquilo que ninguém viu, mas pensar o que ninguém ainda pensou sobre aquilo que todo mundo vê."

(Arthur Schopenhauer). 


\section{RESUMO}

ABREU, N. P. Análise da expressão do fator de transcrição $\mathrm{Sf}-1$ e sua regulação em culturas primárias de adrenal de rato: o papel de Pod-1/TCF 21. 2013. 56 f. Dissertação (Mestrado em Ciências Morfofuncionais) - Instituto de Ciências Biomédicas, Universidade de São Paulo, São Paulo, 2013.

O córtex adrenal é dividido em três zonas distintas: a glomerulosa, a fasciculada e a reticulada, e cada zona é responsável pelas síntese e secreção de diferentes tipos de esteroides. O fator esteroidogênico 1 (SF-1) é um fator de transcrição envolvido no desenvolvimento, na produção de esteroides e na proliferação do córtex adrenal, e é regulado por vários fatores. Existem evidências de que POD-1/TCF21, que é uma proteína do tipo bHLH, pode estar envolvida na regulação de SF-1, inibindo sua expressão e modulando potencialmente suas funções nas células esteroidogênicas. No entanto a expressão de ambos os fatores, SF-1 e POD-1, a relação entre eles e o mecanismo de regulação em células normais do córtex da suprarrenal ainda não estão esclarecidos. O objetivo deste trabalho foi determinar se Pod-1 regula a expressão de Sf-1 através da hiperexpressão de Pod-1 em culturas primárias de células do córtex adrenal de rato. Foi analisada a expressão endógena de Sf-1 e de Pod-1, através da reação de RT-PCR quantitativo, em células isoladas do córtex adrenal, células glomerulosas $(\mathrm{G})$ e células fasciculadas/reticuladas $(\mathrm{F} / \mathrm{R})$, bem como em células transientemente transfectadas com o plasmídeo CMVMycPod-1. Os resultados mostraram que Sf-1 está mais expresso nas células $\mathrm{F} / \mathrm{R}$ do que nas células $\mathrm{G}$, embora essa diferença não tenha sido observada na análise por imunoistoquímica. Além disso, ambos os tipos celulares apresentaram baixa expressão endógena de Pod-1. Foram obtidas, através de transfecção com CMVMycPod-1, células G e F/R com alta expressão de Pod-1. As células F/R transfectadas apresentaram um aumento estatisticamente significante da expressão de Sf-1, o que não ocorreu com as células G. Esses resultados sugerem um mecanismo de ação de Pod-1 no controle da expressão de Sf-1 em células adrenocorticais normais, distintamente do observado em células de tumores adrenais e em outras células esteroidogênicas.

Palavras-chave: Suprarrenal. Cultura de células primárias de rato. Células Glomerulosas. Células Fasciculadas. Células Reticuladas. Sf-1. Pod-1/TCF21. 


\begin{abstract}
ABREU, N. P. Analysis of Sf-1 transcription factor and its regulation in rat adrenal cell primary culture: the role of Pod-1/TCF21. 2013. 56 p. Masters thesis (Morphofunctional Science) - Instituto de Ciências Biomédicas, Universidade de São Paulo, São Paulo, 2013.
\end{abstract}

The adrenal cortex is divided into three distinct zones: a glomerulosa (ZG), fasciculata and reticularis ( $\mathrm{ZF}$ and $\mathrm{ZR}$ ). Each zone is responsible for the synthesis and secretion of different kinds of steroids. SF-1 is a transcription factor involved in the development, steroids production and adrenal cortex proliferation and is regulated by several factors. There are evidences that suggest that POD-1/TCF21, which is a bHLH protein, may be involved in the inhibition of SF-1 and hence potentially modulating the SF-1 function in steroidogenic cells. However, expression of both factors SF-1 and POD-1, the relation between them and the regulatory mechanism of Sf-1 in normal adrenocortical cells is still unclear. The aim of this study was to determine whether Pod-1 regulates the expression of Sf-1 by overexpression of Pod-1 in primary cell cultures of rat adrenal cortex. We analyzed the expression of endogenous Sf-1 and Pod-1 by RT-PCR quantitative in cells isolated from the adrenal cortex, $\mathrm{G}$ and F/R cells, and also in cells transfected with plasmid CMVMycPod-1. The results showed that the SF-1 expression is higher in $F / R$ cells than the $G$ cells although this difference was not observed in the analysis by immunohistochemistry. Moreover, both cell types showed low endogenous expression of Pod-1. An overexpression of Pod-1 in both cell types was obtained by transfection with CMVMycPod-1. Analysis of Sf-1 expression in these cells showed a statistically significant increase in the Sf-1 expression in F/R cells but not in $G$ cells. These results suggest a mechanism of action of Pod- 1 in the regulation of Sf-1 in normal cells, which is distinct of what has been described in adrenocortical tumor cells and other steroidogenic cells.

Keywords: Adrenal. Rat primary cell culture. Glomerulosa cells. Fasciculata cells. Reticularis cells. Sf-1. Pod-1/TCF21. 


\section{LISTA DE ABREVIATURAS}

ACTH= hormônio adrenocorticotrófico

$\mathrm{AGP}=$ primórdio adrenogonadal

$\mathrm{AKR} 1 \mathrm{~B} 7=$ aldose reductase-like protein

$\mathrm{AMH}=$ hormônio anti-muleriano

bHLH= basic helix-loop-helix

$\mathrm{BSA}=$ albumina

cDNA $=$ DNA complementar

$\mathrm{CRH}=$ hormônio liberador de corticotropina

DAPI $=\left(46^{\prime}-\right.$ diamidina- 2 fenilindol $)$

DNA= ácido desoxirribonucleico

DAX-1 $=$ dosage-sensitive sex reversal

$\mathrm{DEPC}=$ dietilpirocarbonato

DHEA = deidroepiandrosterona

DMEM= eagle modificado por dulbeco

DNaseI $=$ desoxirribonuclease I

DTT $=$ dithiothreitol

$\mathrm{F} / \mathrm{R}=$ células fasciculada/reticulada

FSH= hormônio folículo estimulante

FTZ-F1 = fushi tarazu fator transcrição 1

$\mathrm{G}=$ células glomerulosas

$\mathrm{GFP}=$ green fluorescent proten

$\mathrm{HAC}=$ hipogonadismo hipogonadotrófico

HPA= hipotálamo-hipófise-adrenal

LH= hormônio luteinizante

$\mathrm{M}-\mathrm{MLV}=$ transcriptase reversa

$\mathrm{M}=$ medula

$\mathrm{MC} 2 \mathrm{R}=$ receptor de melanocortina 2

$\mathrm{NFY}=$ fator nuclear $\mathrm{Y}$

$\mathrm{POMC}=$ proopiomelanocortina

$\mathrm{PBS}=$ solução fosfato tamponada 
$\mathrm{PCR}=$ polymerase chain reaction

$\mathrm{RNA}=$ ácido ribonucleico

RNaseOUT $=$ recombinant

$\mathrm{DP}=$ desvio padrão

SDS= dodecil sulfato de sódio

$\mathrm{SFB}=$ soro fetal bovino

SF-1/NRA1/Ad4BP= fator esteroidogênico 1

SRY= região determinação sexual Y

$\mathrm{StAR}=$ esteroidogenic acute regulatory protein

$\mathrm{USF}=$ upstream stimulatory

$\mathrm{VMH}=$ região ventromedial do hipotálamo

$\mathrm{ZG}=$ zona glomerulosa

$\mathrm{ZF}=$ zona fasciculada

$\mathrm{ZR}=$ zona reticulada 


\section{LISTA DE SIGLAS}

CEUA= Comissão de Ética no Uso de Animais

ICB = Instituto de Ciências Biomédicas

LIM= Laboratório de Investigação Médica

FMUSP= Faculdade de Medicina da Universidade de São Paulo

USP $=$ Universidade de São Paulo 


\section{LISTA DE SÍMBOLOS}

${ }^{\circ} \mathrm{C}=$ Celsius

$\mathrm{CO}_{2}=$ gás carbônico

$\mathrm{cm}=$ centímetro

$\mathrm{g}=$ grama

$\mathrm{mg}=$ miligrama

$\mathrm{h}=$ horas

$\mathrm{H}_{2} \mathrm{O}_{2}=$ peróxido de hidrogênio

$\mathrm{L}=$ litro

$\mu \mathrm{g}=$ micrograma

$\mu \mathrm{l}=$ microlitro

$\mu \mathrm{m}=$ micrometro

$\min =$ minutos

$\mathrm{ml}=$ mililitro

$\mathrm{mm}=$ milímetro

$\mu \mathrm{M}=$ micromolar

$\mathrm{nm}=$ nanômetro

$\%=$ porcentagem

rpm= rotação por minuto

$\mathrm{s}=$ segundo

$\mathrm{V}=$ volts 


\section{SUMÁRIO}

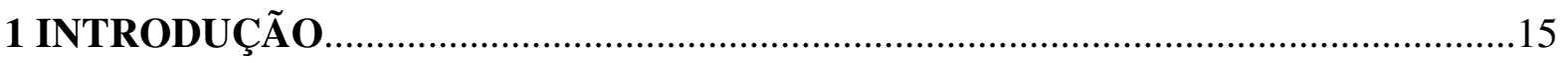

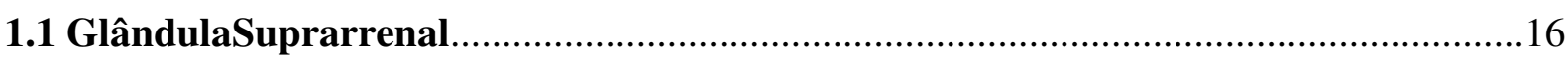

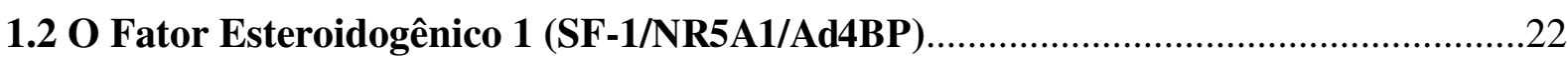

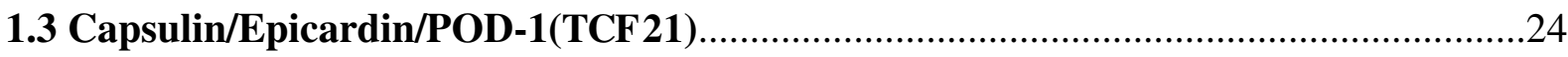

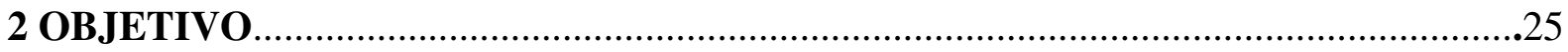

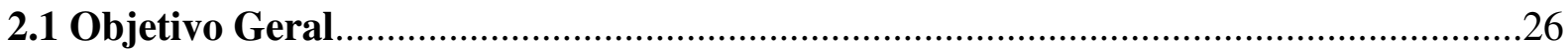

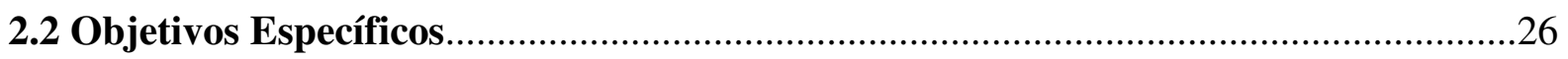

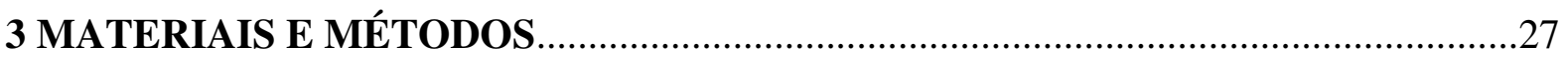

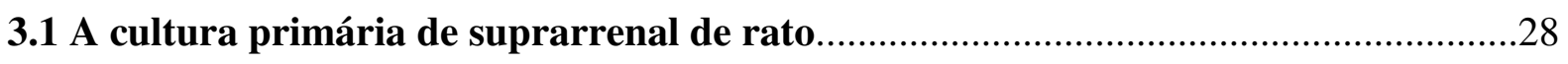

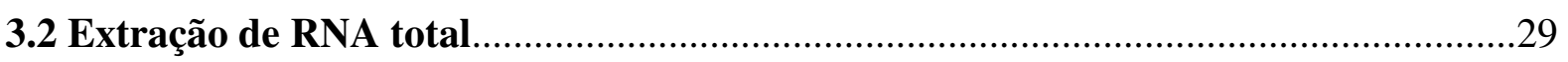

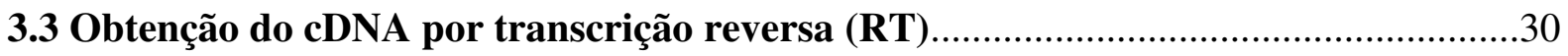

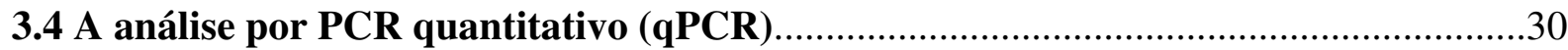

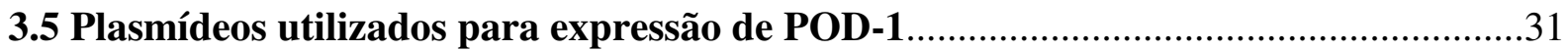

3.6 Transfecção transiente das culturas primárias com os plasmídeos com e sem o

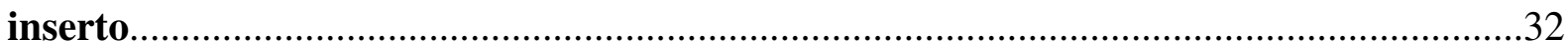

3.7 Análise da eficiência do método de transfecção utilizado.........................................32

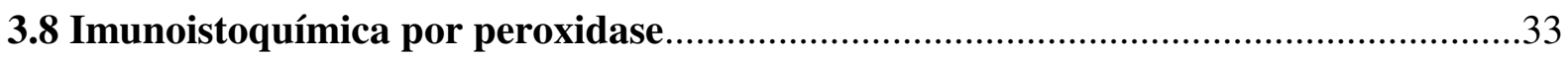

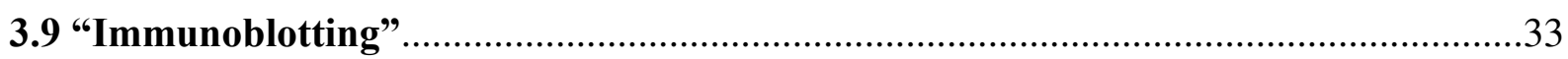

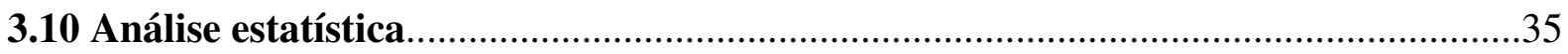

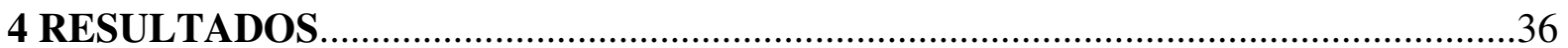

4.1 Análise da expressão gênica endógena de Sf-1 nas células do córtex adrenal.............37

4.2 Imunolocalização da proteína SF-1 no córtex da adrenal de rato..............................38

4.3 Análise da expressão do gene Pod-1 nas células do córtex adrenal............................39

4.4 Análise do gene Pod-1 em culturas primárias das células G e FR transfectadas com os plasmídeos pCMVMyc e pCMVMycPod-1....

4.5 Análise da expressão da proteína POD-1 nas culturas primárias transfectadas com das pCMVMyc-Pod-1......

4.6 Análise da expressão do gene $\mathrm{Sf}-1$ nas culturas primárias das células $G$ e $F / R$ transfectadas com pCMVMyc e pCMVMycPod-1.......................................................45

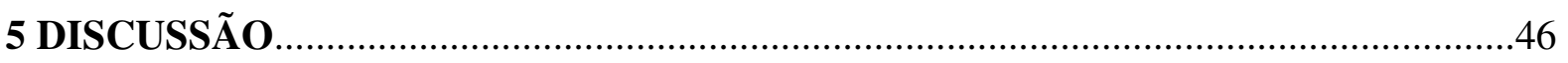

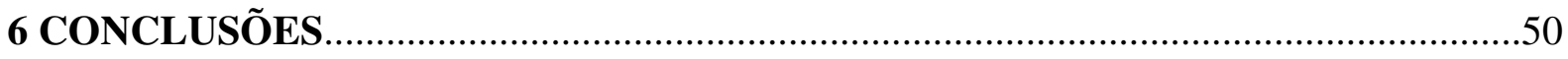

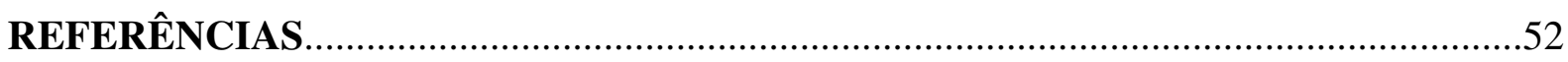


1 INTRODUÇÃO 


\subsection{Glândula Suprarrenal}

A anatomia das glândulas suprarrenais foi primeiramente descrita por Bartholomeo Eustachius, em 1953. Thomas Addison, em 1855, demonstrou a função da glândula. Inicialmente, o termo suprarrenal foi usado para indicar a situação topográfica das glândulas, sendo, posteriormente, aplicado à nomenclatura da glândula. A partir de 1875, a denominação adrenal começa surgir na língua inglesa. O prefixo ad- é mais adequado para animais quadrúpedes, como o rato, o que significa que as glândulas estão próximas dos rins. O prefixo supra- é mais apropriado para o humano - sua posição bípede faz que a posição das glândulas seja acima dos rins.

As glândulas suprarrenais estão localizadas na cavidade abdominal em posição retroperitonial sobre o polo cranial dos rins. O tamanho da suprarrenal varia conforme a idade e com as condições fisiológicas de cada indivíduo, mas, em geral, cada glândula mede $3-5 \mathrm{~cm}$ de comprimento e pesa cerca de 3,5-5 g em um humano adulto. A forma e as relações das suprarrenais humanas são diferentes entre os lados direito e esquerdo do corpo. A suprarrenal direita (Figura 1A e 1C) tem um formato piramidal, com o ápice para cima e a base que se ajusta ao polo superior do rim direito. A suprarrenal esquerda (Figura 1B e 1D) é mais alongada que a direita, com formato semilunar (MOORE, 1994). 
Figura 1 - Relações Anatômicas das Suprarrenais

A

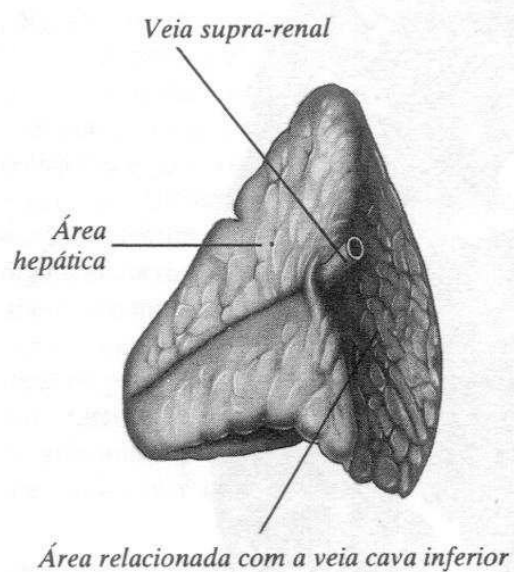

DIREITA

C

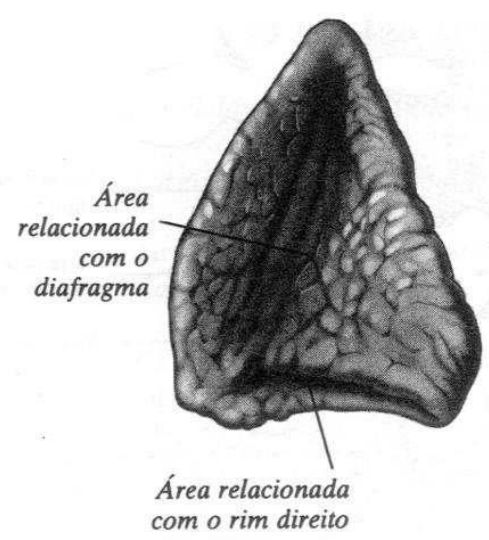

DIREITA

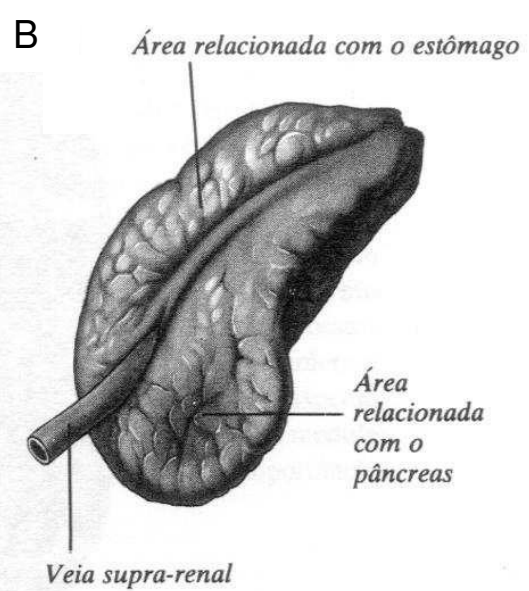

ESQUERDA

$\mathrm{D}$

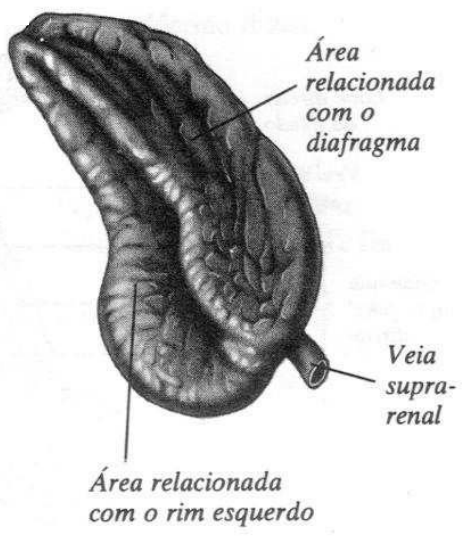

ESQUERDA

Relações anatômicas das suprarrenais direita e esquerda com os diferentes órgãos abdominais. Fonte: Gray, 1998.

As glândulas suprarrenais, devido à função endócrina, são órgãos bem vascularizados. No ser humano, são geralmente irrigadas por três pedículos arteriais em forma de garfo: artérias superiores, artérias médias e artérias inferiores (DÂNGELO; FATTINI, 2007; MOORE, 1994).

O retorno venoso do córtex e da medula é feito por uma única veia, de maneira que a veia suprarrenal direita drena diretamente na veia cava inferior e a veia suprarrenal esquerda, drena para a veia renal esquerda e então para a veia cava inferior. Na cápsula, a drenagem venosa é feita por veias próprias (MOORE, 1994).

A rede linfática que drena as suprarrenais tem origem em um plexo situado profundamente na cápsula e na medula. A grande parte dos vasos linfáticos drena para os linfonodos lombares superiores (MOORE, 1994). 
No rato, as suprarrenais tem uma coloração castanha e estão localizadas na gordura retroperitonial, próximas ao polo cranial de cada rim e aderidas aos músculos sub-lombares. A suprarrenal direita tem forma semelhante a um grão de feijão e está situada abaixo do lobo caudado do fígado, apresentando seu eixo mais longo na direção caudo-medial. Suas dimensões são: 4-5,5 mm de comprimento, 3-4,5 mm de largura e 2,8-3 mm de espessura, e seu peso médio é de 21,8 mg nos machos e $25,7 \mathrm{mg}$ nas fêmeas. Em formato ovoide, a glândula suprarrenal esquerda, está ligeiramente em posicição medial ao polo cranial do rim esquerdo, apresentando seu eixo mais longo na direção ventro-lateral e suas proporções são: 4,5-5,5 mm de comprimento, 3,2-4,5 $\mathrm{mm}$ de largura e 2,5-2,8 $\mathrm{mm}$ de espessura. Seu peso médio é de 31,6 mg em fêmeas e 20,5 mg em machos. Uma peculiaridade em relação às suprarrenais de rato é que elas apresentam dimorfismo sexual, sendo relativamente maiores nas fêmeas do que nos machos (HEBEL; STROMBERG, 1986).

O suprimento sanguíneo das suprarrenais de ratos é constituído pela artéria suprarrenal superior e pela artéria suprarrenal inferior. Diferente dos humanos, os ratos não possuem artéria suprarrenal média. Essas artérias penetram a cápsula suprarrenal formando um plexo subcapsular, do qual surgem três grupos de vasos arteriais: artérias da cápsula, artérias do córtex e artérias da medula, isso ocorre tanto em humanos como em ratos (POPESKO; REJTOVÁ; HORÁK, 2002).

A inervação da medula da suprarrenal é realizada através dos nervos esplâncnicos abdominais, pélvicos e ramo do plexo celíaco. O córtex da suprarrenal aparentemente recebe somente um suprimento nervoso vasomotor (POPESKO; REJTOVÁ; HORÁK, 2002).

É possível observar em uma secção longitudinal de uma suprarrenal humana duas regiões distintas: o córtex, porção periférica e a medula, a porção mais interna da glândula. Essas regiões são consideradas órgãos distintos, de origens embriológicas diferentes que estão topograficamente unidos por uma cápsula de tecido conjuntivo (Figura 2) (JUNQUEIRA; CARNEIRO, 2004). 
Figura 2 - Secção longitudinal da adrenal humana

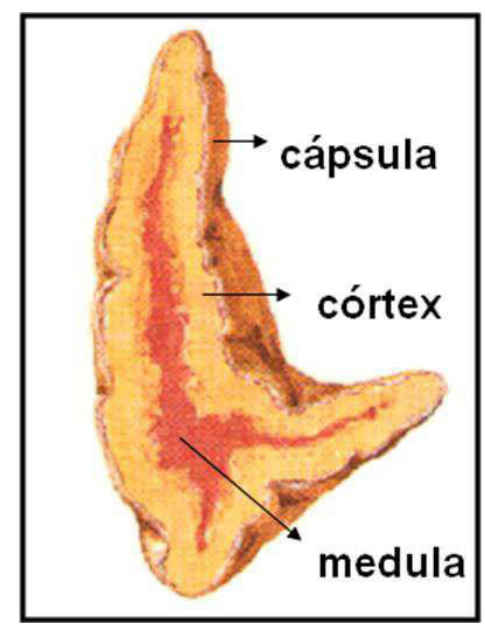

Secção longitudinal de adrenal humana indicando cápsula, córtex e medula. Fonte: Netter, 2008.

A medula da suprarrenal é formada por células com formato poliédrico, são denominadas de células cromafins por corarem com sais de cromo e tem sua origem embriológica na neuroectoderme (células da crista neural). Estas células estão organizadas em cordões ao redor dos capilares sanguíneos e das vênulas e produzem hormônios como: as catecolaminas adrenalina (epinefrina) e noradrenalina (norepinefrina). As células cromafins estão sempre localizadas entre uma artéria e uma veia, de maneira que os grânulos citoplasmáticos de secreção se acumulam no polo celular voltado para a veia, aonde são lançados (JUNQUEIRA; CARNEIRO, 2004).

O córtex da glândula suprarrenal é formado por células derivadas do epitélio celomático, mais especificamente da mesoderme da parede abdominal posterior e contribui para aproximadamente $80-90 \%$ do peso total da glândula no indivíduo adulto. As células corticais são epitelioides, de formato poliédrico e estão organizadas em três zonas histologicamente bem definidas (Figura 3) denominadas zona Glomerulosa (ZG), zona Fasciculada (ZF) e zona reticulada (ZR) (JUNQUEIRA; CARNEIRO, 2004). 
Figura 3 - Fotomicrografias representativas de cortes histológicos da suprarrenal de rato
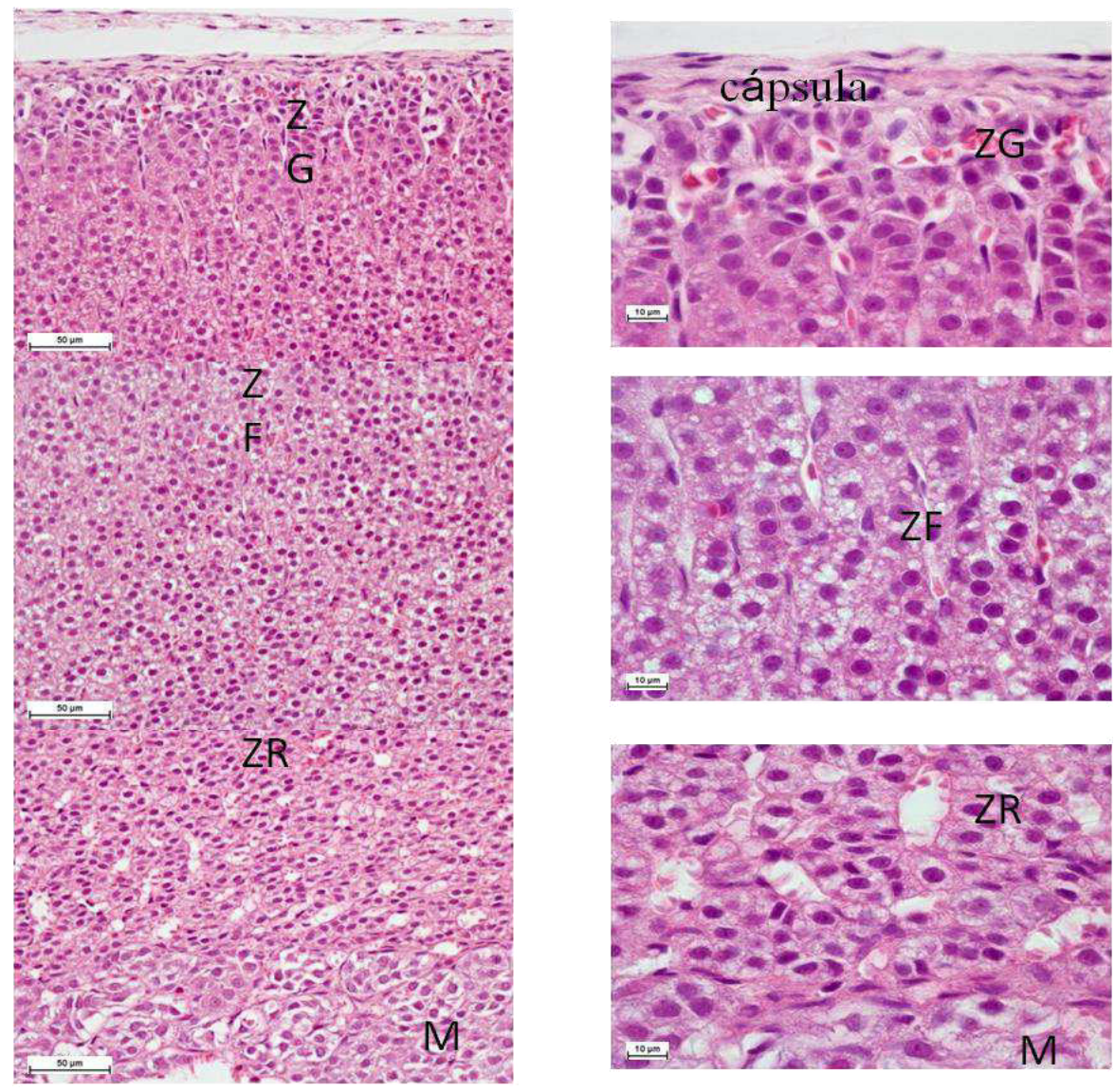

Cortes histológicos corados com hematoxilina e eosina. Córtex adrenal, zona glomerulosa (ZG), zona fasciculada (ZF) e zona reticulada (ZR).

Fonte: Adaptado de Torres e Lotfi, 2008.

A zona glomerulosa $(\mathrm{ZG})$ está localizada imediatamente abaixo da cápsula é formada por células em geral pequenas, colunares, de núcleo esférico único e excêntrico, citoplasma acidófilo, contendo grumos basófilos e gotículas lipídicas e é uma região relativamente estreita (15\% do volume total da glândula). As células da ZG sintetizam e secretam hormônios envolvidos com a homeostase de eletrólitos no líquido extracelular, os mineralocorticóides, como a aldosterona, que age nos túbulos renais estimulando a reabsorção de sódio (JUNQUEIRA; CARNEIRO, 2004).

A zona fasciculada (ZF) está localizada na região intermediária do córtex e é a maior em grande parte dos mamíferos (ocupa $65 \%$ do volume total da glândula). As células da ZF estão organizadas em colunas paralelas disposto perpendicularmente à superfície da glândula, intercaladas com capilares. São poliédricas, de citoplasma com um grande número de gotículas lipídicas. Esta zona secreta os glicocorticoides, o cortisol em primatas e a corticosterona em roedores. Os glicocorticoides têm como ações primárias o aumento da gliconeogênese, a síntese e o armazenamento de glicogênio, a inibição da utilização de glicose 
pelos tecidos periféricos, a mobilização de ácidos graxos do tecido adiposo, num esforço conjunto de aumentar e manter o nível plasmático de glicose. A liberação dos glicocorticoides é regulada pelo hormônio adrenocorticotrófico (ACTH) (JUNQUEIRA; CARNEIRO, 2004).

A zona reticulada (ZR) é menor que as demais e a mais interna do córtex (ocupa 7\% do volume total da glâdula), adjacente à medula. Suas células são menores que as células das demais zonas, arranjadas em forma de cordões entrelaçados formando uma rede anastomosada, possuem núcleo picnótico e citoplasma eosinófilo. A ZR humana secreta andrógenos (hormônios sexuais masculinos), a deidroepiandrosterona (DHEA) e DHEA sulfatada, e estrogênicos (hormônios sexuais femininos) (JUNQUEIRA; CARNEIRO, 2004). Em ratos, não ocorre à produção de DHEA no córtex adrenal.

O papel básico desempenhado pela glândula suprarrenal é manter a homeostase do organismo, de maneira que estímulos fisiológicos ou patológicos provocam alterações do eixo hipotálamo-hipófise-adrenal, conhecido como eixo HPA. A produção e a liberação dos corticosteroides são controladas por esse eixo. Estímulos provenientes de muitas regiões do sistema nervoso induzem as células nos núcleos hipotalâmicos, paraventricular e supra-óptico, à produção do hormônio liberador de corticotropina (CRH). O CRH é um peptídeo de 41 aminoácidos que chega à adenohipófise por meio do sistema porta-hipofisário, e liga-se a receptores específicos das células corticotróficas, estimulando a liberação do ACTH. O ACTH produzido e secretado pela hipófise anterior é um hormônio peptídico proveniente de uma molécula precursora, a proopiomelanocortina (POMC) (WHITE; GIBSON, 1998). O mecanismo pelo qual o ACTH estimula as células adrenocorticais a produzirem esteroides, a partir do colesterol endógeno, envolve a ação de várias enzimas pertencentes à família do citocromo P450 (WHITE; GIBSON, 1998).

A transcrição dos genes das enzimas dessa família nas células esteroidogênicas, da glândula suprarrenal e das gônadas é regulada por um fator de transcrição denominado fator esteroidogênico-1 (SF-1) ou "adrenal 4-binding protein" (Ad4BP) (MOROHASHI et al., 1994). 


\subsection{O Fator Esteroidogênico 1 (SF-1/NR5A1/Ad4BP)}

O SF-1/NR5A1/Ad4BP é um fator de transcrição que foi o primeiro a ser descrito como um membro órfão dos receptores nucleares (LALA; RICE; PARKER, 1992; MOROHASHI et al., 1994). Ele liga-se como um monômero ao DNA, devido a uma estrutura de dedo de zinco na sua região N-terminal, que é um domínio de ligação ao DNA. Este fator é semelhante ao fator Fushi Tarazu Transcription Factor 1 (FTZ-F1) da Drosófila, que está associado ao desenvolvimento da Drosophila sp, e é altamente conservado entre as espécies (LAVORGNA et al., 1991).

O SF-1 está expresso no córtex da suprarrenal, nas células testiculares de Leydig e de Sertoli, nas células da granulosa e da teca no ovário, e sua expressão foi também observada na hipófise, na região ventromedial do hipotálamo $(\mathrm{VMH})$, na pele e no baço (BARNHART; MELLON, 1994; HONDA et al., 1993; IKEDA et al., 1993; INGRAHAM et al., 1994; MOROHASHI et al., 1994, 1999). Este exerce um papel essencial no desenvolvimento, na regulação e na função dos tecidos esteroidogênicos (SHIMMER; WHITE, 2010).

Durante o processo de desenvolvimento embrionário, a expressão de SF-1 ocorre primeiramente no primórdio urogenital e como primeiro marcador do processo de diferenciação das gônadas e das suprarrenais (HANLEY et al., 1999; MOROHASHI et al., 1995). Estudos com camundongos "knockout" para SF-1 (SF-1 $\left.{ }^{-/}\right)$mostraram que, após o nascimento, os animais do sexo masculino apresentaram reversão da genitália externa, baixa concentração de corticosterona e altos níveis de ACTH, o que acarretou a morte desses animais por insuficiência de esteroides, após 8 dias do nascimento. Além disso, esses animais apresentaram ausência completa das adrenais e das gônadas, o que confirma a importância do papel de SF-1 no desenvolvimento de tecidos produtores de esteroides (LUO; IKEDA; PARKER, 1994; SADOVSKY et al., 1995). Por outro lado, os camundongos SF-1 heterozigotos $\left(\mathrm{SF}^{-1}{ }^{+-}\right)$apresentaram defeitos histológicos na suprarrenal, associados com um comprometimento na produção de corticosterona em resposta ao estresse (BLAND et al., 2000).

SF-1 foi inicialmente identificado como um fator que tem a capacidade de regular a transcrição dos genes das enzimas pertencentes à família P450 citocromo hidroxilase (CYP) nas células esteroidogênicas adrenais e nas gônadas (CLEMENTS et al., 1994; MOROHASHI et al., 1994; RICE et al., 1990; VAL et al., 2003). SF-1 regula diferentes enzimas esteroidogênicas (P450SCC, CYP17, CYP11B1, CYP21 e 3ß-HSD), a enzima StAR (“steroidogenic acute regulatory protein"), o receptor de Melanocortina 2 (MC2R), que é o 
receptor do ACTH, e o Hormônio Folículo Estimulante (FSH) (MARCHAL et al., 1998; NAVILLE et al., 1998, 1999).

Além de SF-1 estar envolvido na esteroidogênese, ele foi apontado por seu papel na proliferação de células adrenocorticais. Estudos in vitro em células tumorais adrenocorticais demonstraram que a dosagem de SF-1 tem forte relação com a regulação da proliferação das células adrenocorticais e diminuição da apoptose, e pode desencadear a formação de tumores em camundongos (DOGHMAN et al., 2007). De fato, SF-1 está hiperexpresso na maioria dos tumores adrenocorticais, sendo significativamente maior em tumores adrenocorticais pediátricos do que em tumores adultos, o que sugere que sua expressão é um fator importante na formação de tumores da suprarrenal (ALMEIDA et al., 2010; FIGUEIREDO et al., 2005; PIANOVSKI et al., 2006).

São descritos alguns sítios de ligações nos primeiros 110 pb da região promotora de SF-1 como: SOX9, CAAT box, Sp1/Sp3 e E-box. A proteína SRY (sex determining region Y), ao ligar-se a SOX9, pode contribuir para a expressão de SF-1 nas células de Sertoli. No sítio CAAT box, liga-se a isoformas do fator nuclear Y (NFY) e, no Sp1/Sp3, liga-se a Sp. Apesar de esses últimos sítios serem descritos nessa região, os seus papeis na atividade do promotor de SF-1 ainda não está claro. O sítio E-box é reconhecido por fatores de transcrição do tipo bHLH (basic helix-loop-helix). Os membros dessa família tem um importante papel no controle da diferenciação celular, na proliferação e na oncogênese (DAGGETT; RICE; HECKER, 2000; KADESCH, 1993; SHEN et al., 2002; WOODSON et al., 1997). O sitio Ebox (CANNTG) é uma sequência responsável pela atividade transcricional de Sf-1 no desenvolvimento e na diferenciação das adrenais e das gônadas (NOMURA et al., 1995). Algumas proteínas do tipo bHLH que formam homodímeros e heterodímeros através do domínio HLH reconhecem a sequência CANNTG nos promotores de genes por elas regulados (MASSARI; MURRE, 2000). Entre elas, estão as proteínas Myc, TFE3, TFEB e USF ("upstream stimulatory factor") (MASSARI; MURE, 2000; NOMURA et al., 1995). O fator USF tem duas isoformas: USF-1 e USF-2, e análises funcionais da regulação transcricional e estrutural do gene Sf-1 sugerem que USF-1 e, em grau menor, USF-2 formam complexos na região E-box do proximal de Sf-1, e estão significativamente envolvidos na transcrição basal desse gene (HARRIS; MELLON, 1998). O fator transcrição SF-1 pode ser regulado por outros fatores de transcrição, como DAX-1 (dosage-sensitive sex reversal/ NR0B1), USF ("upstream stimulatory factor") e POD-1 (TCF21/Epicardin/Capsulin), que podem estar relacionados com o nível de expressão de SF-1 no período do desenvolvimento adrenal e gonadal (HARRIS; MELLON 1998; ITO; YU; JAMESON, 1997; TAMURA et al., 2001). 


\subsection{Capsulin/Epicardin/POD-1(TCF21)}

POD-1 (TCF21/Capsulina/Epicardina) é uma proteína do tipo bHLH e membro de uma família de proteínas regulatórias envolvidas na diferenciação celular de tecidos neuronais, cardíacos, hematopoiéticos e pancreático. POD-1 é expresso em células mesenquimais dos rins, pulmões, pâncreas, intestino e adrenais, e durante o processo de desenvolvimento dos sistemas cardiovascular, respiratório e gastrintestinal. Foi assim denominado por ter sido primeiramente descrito em podócitos dos glomérulos renais (LU; RICHARDSON; OLSON, 1998; QUAGGIN et al., 1998).

O estudo de camundongos "knock-out" para Pod-1 (Pod-1 ${ }^{-1-}$ ) mostrou ausência de glomérulos e de podócitos maduros, má formação no músculo facial, no desenvolvimento esplênico e morte após o nascimento por insuficiência respiratória devido à ausência dos alvéolos (LU et al., 2000; QUAGGIN et al., 1999). Ensaios de hibridização nas gônadas de camundongos Pod-1 ${ }^{-/-}$mostrou que a expressão de Pod-1 pode ser diferente de acordo com sexo e estágio do embrião durante o processo de gonadogênese masculina e feminina. Camundongos machos Pod-1 $1^{-/}$apresentaram genitália externa com características femininas, e uma expressão aberrante de Sf-1 na crista urogenital, impedindo o processo normal da gonadogênese (CUI et al., 2004; TAMURA et al., 2001). Existem evidências, portanto, que sugerem que Pod-1 pode regular Sf-1. Todavia a relação entre esses fatores de transcrição e seus mecanismos em células normais adrenocorticais não está ainda esclarecida.

Com base nesses resultados e os descritos na literatura sobre a importância de SF-1 na proliferação de células esteroidogênicas, propomos uma investigação sobre a expressão de Pod-1 e Sf-1 em células normais isoladas da adrenal de rato, culturas primárias de células da glomerulosa e células fasciculadas/reticulares. Portanto, temos como hipótese que Sf-1 pode ser modulado por Pod-1, e que esse controle tem um papel importante na proliferação do córtex adrenal. 
2 OBJETIVO 


\subsection{Objetivo Geral}

Determinar se o fator de transcrição Pod-1, através da sua hiperexpressão, regula a expressão gênica e proteica de Sf-1 em culturas primárias do córtex adrenal de rato.

\subsection{Objetivos Específicos}

1) Analisar, por PCR quantitativo, a expressão endógena de Sf-1 e Pod-1 nas células isoladas da zona glomerulosa (células G) e das zonas fasciculada e reticulada (células F/R).

2) Analisar, por PCR quantitativo, a expressão de $\mathrm{Sf}-1$ em células $\mathrm{G}$ e células $\mathrm{F} / \mathrm{R}$ transfectadas com plasmídeos que expressam Pod-1.

3) Analisar a expressão proteica de SF-1 por imunoistoquímica na glândula adremal. 
3 MATERIAIS E MÉTODOS 


\subsection{A cultura primária de suprarrenal de rato}

Os procedimentos utilizados estão descritos no Protocolo para uso de animais em experimentação atualmente registrado sob no 031 de 01/04/2011, sob o projeto intitulado "Estudo da expressão do fator de transcrição Sf-1 e sua regulação em culturas primárias de adrenal de rato: o papel de Pod-1/TCF21", que está de acordo com os Princípios Éticos de Experimentação Animal e foi aprovado pela Comissão de Ética no Uso de Animais (CEUA) do Instituto de Ciências Biomédicas (ICB) da Universidade de São Paulo (USP). O protocolo de obtenção das culturas primárias de suprarrenal de rato está descrito em Mattos e Lotfi (2005, 2011). Foram utilizados ratos machos (Rattus norvegicus) da linhagem Sprague Dawley, (50 e 60 dias) pesando entre 250-300 g, mantidos no Biotério do Departamento de Anatomia do Instituto de Ciências Biomédicas da USP, sob condições controladas de luz (12 h/12 h), ar e temperatura, e com livre acesso a ração e a água. Os animais foram sacrificados por decapitação em guilhotina no período da manhã seguido de uma incisão ventral mediana profunda no abdômen (Figura 4A). O intestino foi rebatido, expondo a região posterior, para que as glândulas pudessem ser retiradas (Figura 4B e C). As glândulas foram mantidas em meio de cultura Eagle modificado por Dulbeco (DMEM) (Gibco, Grand Island, NY, USA), suplementado com $25 \mu \mathrm{g} / \mathrm{ml}$ de ampicilina (Sigma-Aldrich Co., St. Louis, MO, USA) e 100 $\mu \mathrm{g} / \mathrm{ml}$ de estreptomicina (Sigma-Aldrich) até seu processamento (Figura 4D).

Em fluxo laminar, as glândulas foram dissecadas, o que consiste em separar a cápsula do restante da glândula (Figura 4E). As cápsulas contendo as células Glomerulosas foram dissociadas em DMEM ( $1 \mathrm{ml} / \mathrm{rato}$ ) com $2 \mathrm{mg} / \mathrm{ml}$ de colagenase liofilizada (Gibco) e $25 \mu \mathrm{g} / \mathrm{ml}$ de desoxirribonuclease I de pâncreas bovino (DNase I) (Sigma-Aldrich) por 20 min a $37{ }^{\circ} \mathrm{C} \mathrm{e}$ $5 \%$ de $\mathrm{CO}_{2}$. O restante da glândula, composto pelas zonas Fasciculada, Reticulada e medula, após ser reduzido a pequenos pedaços, foi digerido por $4 \mathrm{mg} / \mathrm{ml}$ de colagenase liofilizada e 25 $\mu \mathrm{g} / \mathrm{ml}$ DNase I em DMEM ( $1 \mathrm{ml} / \mathrm{rato})$ por $40 \mathrm{~min}$, a $37{ }^{\circ} \mathrm{C}$ e $5 \%$ de $\mathrm{CO}_{2}$. Após a digestão enzimática, as soluções foram ressuspendidas com pipeta volumétrica para a dissociação mecânica. As suspensões de células foram filtradas em filtro de náilon de $100 \mu \mathrm{m}$ (BD Biosciences, Bedford, MA, EUA) e diluídas em $45 \mathrm{ml}$ em DMEM e depois centrifugadas a $700 \mathrm{rpm}$ por $12 \mathrm{~min}$, a temperatura ambiente. Após a centrifugação, o pellet de células foi ressuspendido em DMEM + 10\% de soro fetal bovino (SFB) (Gibco) e as células foram plaqueadas conforme o experimento. 
Figura 4 - Fotos representativas da obtenção e do processamento das glândulas suprarrenais de ratos para a preparação das culturas de células primárias.
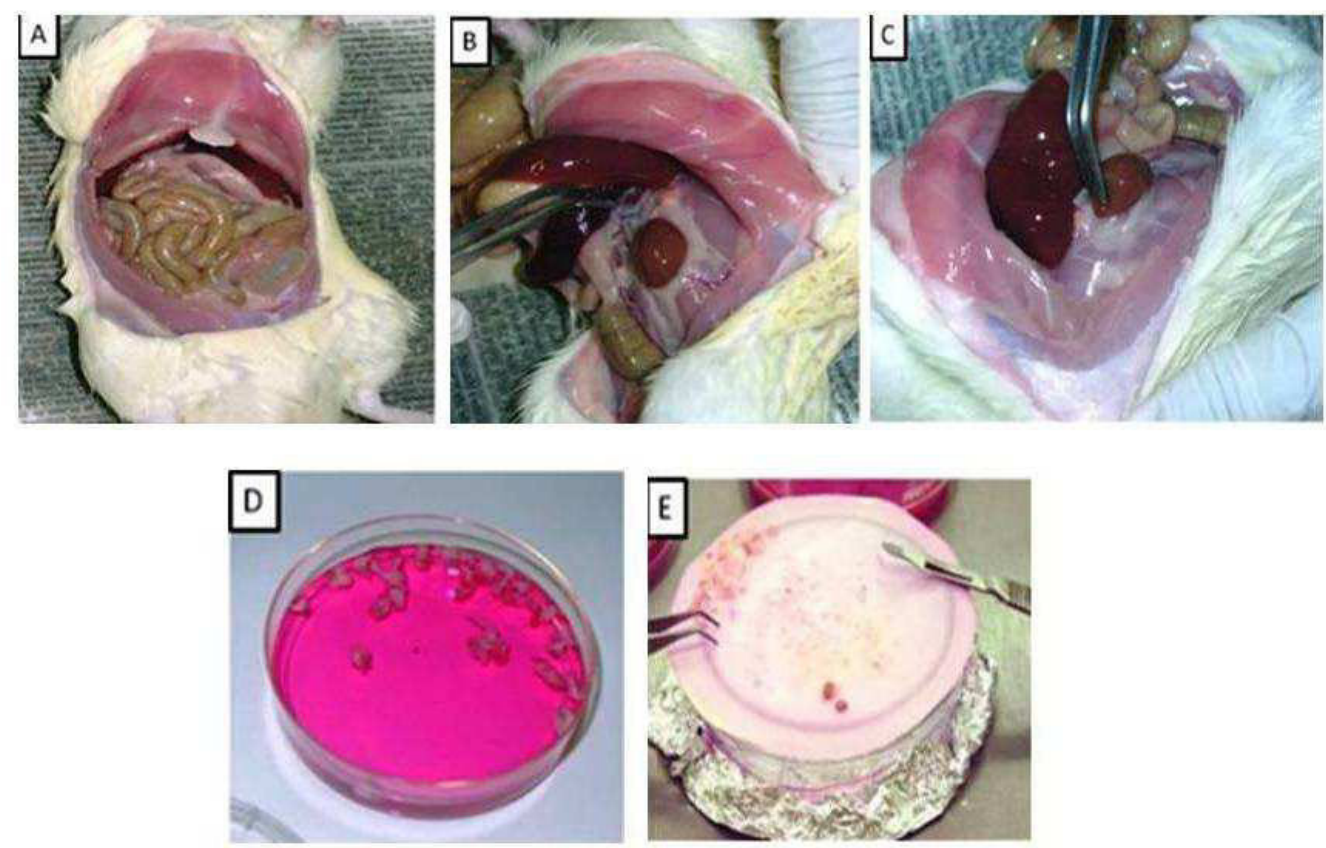

Sequência de obtenção e dissecção das glândulas da suprarrenal de rato. A: abdome exposto de rato macho adulto, B: rebatimento dos intestinos para exposição da suprarrenal esquerda, C: o mesmo para a suprarrenal direita, D: as glândulas mantidas em meio de cultura aguardando a dissecação; E: as glândulas sendo dissecadas sobre papel filtro.

\subsection{Extração de RNA total}

Aproximadamente $8 \times 10^{5}$ de células G e F/R foram plaqueadas em placas de Petri de $60 \mathrm{~mm}$, cujo meio de cultura foi trocado 24 h após o plaqueamento. Após 48 h, essas células foram lisadas em TRIZOL® (Life Technologies, Carlsbad, CA, USA). Para extração de RNA dos tecidos de pulmão $(\mathrm{P})$ e testículo $(\mathrm{T})$, o tecido foi macerado com TRIZOL® no homogeneizador até a dissociação total do fragmento de tecido. O lisado foi recolhido e a ele adicionado $200 \mu \mathrm{l}$ de clorofórmio por ml de TRIZOL® seguido de centrifugação (12.000 rpm à $-4{ }^{\circ} \mathrm{C}$ por $15 \mathrm{~min}$ ). Após a separação das fases, a fase incolor foi recolhida e a ela adicionada $500 \mu \mathrm{l}$ álcool isopropílico, seguido de nova centrifugação. O sobrenadante foi descartado e ao pellet formado foi adicionado $1 \mathrm{ml}$ de etanol $75 \%$, seguido de nova centrifugação. Após o descarte do sobrenadante, foi adicionado $20 \mu 1$ de água com dietilpirocarbonato (DEPC) e as amostras foram mantidas "overnigth" a $4{ }^{\circ} \mathrm{C}$, e depois estocadas a $-80^{\circ} \mathrm{C}$. Antes do RNA total ser utilizado, as amostras foram tratadas com kit TURBO DNA-free® (Ambion, Austin, TX, USA), quantificadas em espectrofotômetro (Synergy-HT-Biotek, Winooski, VT, USA) em 
um comprimento de onda de 260/280 nm, e analisadas em gel de agarose para constatação da integridade do RNA.

\subsection{Obtenção do cDNA por transcrição reversa (RT)}

O cDNA foi obtido utilizando M-MLV Reverse Transcriptase (Life Technologies) através da utilização do protocolo fornecido pelo fabricante. Foram utilizados $1 \mu \mathrm{g}$ de RNA total, $1 \mu 1$ de oligo dT, $1 \mu 1$ de DNTP mix (Life Technologies), que foram completados para um volume final de $12 \mu \mathrm{l}$ de água DEPC. A reação foi aquecida a $65^{\circ} \mathrm{C}$ por $5 \mathrm{~min}$ e em seguida resfriada em gelo. Após a adição de $4 \mu 1$ de Buffer (5X), $2 \mu 1$ de DTT Dithiothreitol, $1 \mu 1$ de RNaseOUT Recombinant Ribonuclease Inhibitor (40 units/ $\mu$ l) (Life Technologies), a reação foi aquecida a $37^{\circ} \mathrm{C}$ por $2 \mathrm{~min}$. Em seguida foi adicionado $1 \mu \mathrm{l}$ de enzima transcriptase reversa (MLV-RT) (Life Technologies), mantida a $37{ }^{\circ} \mathrm{C}$ por $50 \mathrm{~min}$, e que depois foi novamente aquecida a $72{ }^{\circ} \mathrm{C}$ por 15 min, para inativação da reação. As amostras foram armazenadas e mantidas a $-20^{\circ} \mathrm{C}$.

\subsection{A análise por PCR quantitativo (qPCR)}

A reação por PCR em tempo real foi realizada através da utilização do kit Platinum SYBR Green qPCR supermix (Life Technologies), conforme instruções do fabricante. As sequências de primers dos genes de interesse estão descritas na Tabela 1. Em tubos "nucleasefree" identificados, foram adicionados $6,25 \mu 1$ de "mix SYBR", 1,44 $\mu 1$ do primer de interesse (solução mãe 2,5 $\mu \mathrm{M}$ ) sense e anti-sense, 0,2 $\mu \mathrm{l}$ cDNA, e água DEPC estéril até completar 12,5 $\mu 1$. As condições de desnaturação, anelamento e amplificação foram padronizadas conforme sugestão do fornecedor, a saber: pré-aquecimento a $50^{\circ} \mathrm{C}$ por $2 \mathrm{~min}$, desnaturação a $95{ }^{\circ} \mathrm{C}$ por 2 min e 40 ciclos de amplificação e quantificação $\left(15\right.$ s a $95{ }^{\circ} \mathrm{C}$ e 60 s a $\left.60{ }^{\circ} \mathrm{C}\right)$, seguido de um período de dissociação de 15 s a $72{ }^{\circ} \mathrm{C}$. Foram realizadas padronizações das concentrações de cDNA para cada um dos primers de interesse. A leitura foi realizada no termociclador RG- 6000 (Corbett Research, Mortlake, NSW, Austrália) e os resultados foram analisados pelo método $2^{-\Delta \Delta} \mathrm{Ct}$ conforme descrito em Livak e Schmittgen (2001). Foram realizadas três reações de PCR de três extrações obtidas de culturas de células primárias diferentes. 
Tabela 1 - Sequências dos primers dos genes Sf-1, Pod-1 e $\beta$-actina que foram utilizados na reação de PCR quantitativo em tempo real.

\section{Primers}

Sf-1

Sense

Anti-sense

Pod-1

Sense

Anti-sense

$\beta$-actina

Sense

Anti-sense
Sequências

GCTGTGTGTTTGGGATGATG

AGACGGAGGAAGGAGTGGTT

GCTCTCCAAGCTGGACACTC

ACACCTCCAAGGTCAGGATG

AGTTCGCCATGGATGACGAT

AAGCCGGCCTTGCACAT

\subsection{Plasmídeos utilizados para expressão de POD-1}

O plasmídeo utilizado foi o CMVMycPod-1 (Figura 5), que foi gentilmente doado pelo Dr. Masataka Nakamura, do Human Gene Science Center (Maxillofacial Orthognathics Tokyo Medical and Dental University), e está descrito em Funato e colaboradores (2003). O cDNA epicardin/capsulin/Pod-1 com 1300 pb foi fundido ao plasmídeo contendo a sequência pCMVMyc (Clontech., Mountain View, CA, USA) com 3800 pb, o que gerou o vetor pCMVMycPod-1 resistente a ampicilina. O plasmídeo sem o inserto epicardin/capsulin/Pod-1 foi preparado por Mônica Malheiros França, aluna de doutorado do nosso laboratório, em colaboração com a Dra. Mariza Gerdulo dos Santos (Laboratório de Hormônios e Genética Molecular, LIM 42, FM-USP, São Paulo). 
Figura 5 - O plasmídeo CMVMycPod-1

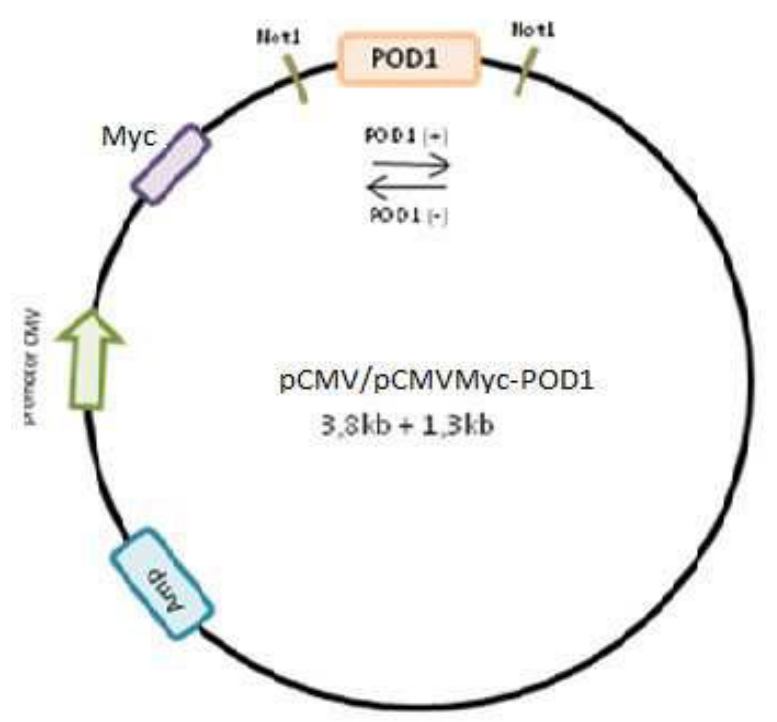

Plasmídeo CMVMyc com 3800 pb fundido com a sequência epicardin/capsulin/Pod-1.

\subsection{Transfecção transiente das culturas primárias com os plasmídeos com e sem o inserto}

Aproximadamente $2 \times 10^{5}$ células foram plaqueadas por poço em placas de 6 poços com $2 \mathrm{ml}$ de meio de cultura DMEM e 10\% de SFB até atingirem uma confluência entre 50$60 \%$. Após $48 \mathrm{~h}$ do plaqueamento, foi preparado o complexo de transfecção contendo $100 \mu \mathrm{l}$ de DMEM, $2 \mu$ lipossomo X-tremeGENE HP DNA Transfection Reagent (Roche, Indianapolis, IN, USA) e $2 \mu \mathrm{g}$ de DNA plasmidial, que foram incubados por $15 \mathrm{~min}$ em temperatura ambiente. O complexo DNA plasmídeo-lipossomo foi adicionado após as células terem sido lavadas com solução fosfato tamponada (PBS). As células foram incubadas em estufa de $\mathrm{CO}_{2}$ a $37^{\circ} \mathrm{C}$ por $5 \mathrm{~h}$ com DMEM sem soro, e após esse período o meio das células foi substituído por meio DMEM contendo 10\% de SFB por um período de $48 \mathrm{~h}$.

\subsection{Análise da eficiência do método de transfecção utilizado}

Para a análise da eficiência da transfecção, foi utilizado um protocolo semelhante com o plasmídeo pCMX-GFP doado pela Dra. Mariza Santos Gerdulo contendo a proteína GFP (Green Fluorescent Protein). Após 48 h do início da transfecção, as células transfectadas com o plasmídeo pCMX-GFP foram fixadas em formaldeído 3,7\%, lavadas com PBS e coradas 
com DAPI (4'6'-diamidina-2-fenilindol) por $8 \mathrm{~min}$ e analisadas em microscópio de fluorescência. Foi realizada uma análise qualitativa, isto é, a observação se as células estavam verdes, e, quando positivo, foi realizada uma quantificação por contagem de pelo menos 3 campos. A quantificação foi realizada com objetiva de 20x e apresentada em porcentagem de células verdes (GFP) por número de células coradas com DAPI, considerada o número de células totais.

\subsection{Imunoistoquímica por peroxidase}

Após a retirada das glândulas, as mesmas foram fixadas em paraformaldeído 3,7\% por $8 \mathrm{~h}$ e depois permaneceram em sacarose $6 \%$ por $24 \mathrm{~h}$. O tecido fixado foi desidratado e incluído em parafina. Foram realizadas secções de $5 \mu \mathrm{m}$ que foram colocadas em lâminas gelatinizadas. Após a desparafinização por 12 h a $60{ }^{\circ} \mathrm{C}$, as secções foram reidratadas em concentrações decrescentes de etanol e finalmente em água Milli-Q. As glândulas foram então preparadas para a reação de imunoistoquímica, inicialmente através do bloqueio da peroxidase endógena, por incubação com peróxido de hidrogênio $\left(\mathrm{H}_{2} \mathrm{O}_{2}\right)$ 0,3\% por 20 min. Em seguida, foi realizada a recuperação antigênica com ácido cítrico 2 g/L pH6.0 por 10 min. Após essa etapa, foi realizada a incubação das secções com o anticorpo primário anti-SF1/NR5A1 (R\&D SYSTEMS, Komaba, Meguro-ku Tokyo, Japão), que foi diluído 1:100 em PBSA $+1 \%$ BSA e mantido "overnight" a $4{ }^{\circ} \mathrm{C}$. Após esse período, o material foi incubado com o anticorpo secundário do kit Vectastain Elite ABC (Vector Laboratories, Burlingame, CA, EUA) na diluição 1:200, por $1 \mathrm{~h}$ à temperatura ambiente. A revelação foi realizada com diaminobenzidina (DAB) (Sigma-Aldrich), seguida de contra-coloração com hematoxilina de Harris (Merck, Darmstadt, Alemanha, UE) e diferenciação com carbonato de lítio saturado (Merck). Após a desidratação em concentrações de etanol crescente e diafanização em xilol, as secções foram montadas em Entellan (Merck) e analisadas em microscópio de luz (Nikon).

\section{9 "Immunoblotting"}

Aproximadamente $5 \times 10^{5}$ de células $\mathrm{G}$ e F/R foram plaqueadas em placas de Petri especiais para culturas primárias Falcon Primária Easy Grip (FALCON, Franklin Lakes, NJ, USA). Após 48 h, as células foram lisadas com tampão de lise RIPA (TrisHCL $50 \mathrm{mM}$; deoxicolato de sódio 0,5\%; NP40 1\%; $\mathrm{NaCl} 150 \mathrm{mM}$; SDS 0,1\%; NaF $50 \mathrm{mM}$ ) contendo inibidores de proteases e fosfatases (Ortovanadato $1 \mathrm{mM}$; PMSF $1 \mathrm{Mm}$; Aprotinina $2 \mu \mathrm{g} / \mathrm{ml}$; 
Pepstatina $2 \mu \mathrm{g} / \mathrm{ml}$; Leupeptina $2 \mu \mathrm{g} / \mathrm{ml}$ ). O lisado recolhido foi centrifugado (14.000 rpm a $4{ }^{\circ} \mathrm{C}$, por $15 \mathrm{~min}$ ), aliquotado e estocado em freezer a $-80{ }^{\circ} \mathrm{C}$. Após a preparação e quantificação de uma curva padrão de albumina bovina (BSA), foi realizada a quantificação da proteína total em $990 \mu$ l de solução de Bradford (Bio-Rad., Hercules, CA, USA) diluída (1:4 em água milli-Q), e $10 \mu \mathrm{l}$ dos lisados que foram analisados em espectrofotômetro (UVmini1240, Shimadzu Corporation, Kyoto, Japão) em comprimento de onda de $595 \mathrm{~nm}$.

As amostras de proteínas totais foram adicionadas ao tampão de amostra (tampão de amostra: Tris-HCl pH 6,8, glicerol, SDS, $\beta$-mercaptoetanol e azul de bromofenol) e desnaturadas a $100{ }^{\circ} \mathrm{C}$ por 5 min. Em seguida, foram aplicadas em gel de poliacrilamida $12 \%$ (SDS-PAGE). Foi utilizado um padrão de peso molecular para identificação das bandas (Fermentas Gmbh, Opeltrasse, St.Leon-Rot, Alemanha). As proteínas foram separadas no gel conforme o peso molecular e transferidas para uma membrana de nitrocelulose em um sistema Semi-Dry (Bio-Rad), por 60 min a 20 V, em um tampão de transferência pH 8,3 (Tris base, SDS, glicina e $20 \%$ metanol). Em seguida, as membranas foram coradas com Ponceau (Merck), para avaliar a qualidade da transferência. Para o bloqueio dos sítios inespecíficos, as membranas foram incubadas na solução de bloqueio: (PBS 0,1\% de BSA 1\% de Tween20) Funato et al. (2003), por 2 h. Em seguida, as membranas foram incubadas "overnight" sob agitação, em câmara fria $\left(4{ }^{\circ} \mathrm{C}\right)$ com o anticorpo primário anti-c-Myc (Clontech) ou $\beta$-actina (Santa Cruz Biotechnology, Santa Cruz, CA, EUA). Em seguida, as membranas foram incubadas com anticorpo secundário anti-coelho ou anti-camundongo (Amersham, GE Healthcare, Little Chalfont, Buckinghamshire, Inglaterra, Reino Unido) por $1 \mathrm{~h}$ em temperatura ambiente sob agitação. A revelação foi realizada através da utilização do kit ECL-Plus (Amersham) que utiliza como substrato o luminol, que, depois de degradado pela enzima do anticorpo secundário, emite luz que impressiona uma chapa de raios X T-MAT G/RA (Carestream Health Inc., Rochester, NY, EUA). As chapas de raio X foram reveladas e fixadas em Kodak (Eastman Kodak Company, Rochester, NY, EUA), e as bandas obtidas foram analisadas em um sistema de captura de imagem Gene Snap 6.05 (Syngene-Synoptic Ltd, Cambridge, Inglaterra, Reino Unido) e quantificadas pelo programa Gene Tools 3.06 (SynGene-Synoptic). 


\subsection{Análise estatística}

Os dados foram apresentados na forma de médias e desvio padrão (DP). A análise estatística foi realizada utilizando o programa GraphPad InStat e o teste t de Student, com intervalo de confiança de $5 \%(\mathrm{p}>0.005)$. 
4 RESULTADO 


\subsection{Análise da expressão gênica endógena de Sf-1 nas células do córtex adrenal}

A expressão de Sf-1 foi analisada nas culturas primárias de células da Glomerulosa (células G) e das células da Fasciculada/Reticulada (células FR) de adrenal de rato. Como controle, foi utilizado mRNA extraído do testículo de rato, tecido produtor de esteroides e que expressa Sf-1. As células G não apresentaram uma expressão de Sf-1 estatisticamente significante em relação ao testículo, enquanto as células FR apresentaram uma expressão 1.48 \pm 0.32 vezes maior ( $p=0.0155$ ) em relação a esse tecido (Figura 6). Além disso, quando foi comparada a expressão de Sf-1 nas células G e nas células FR, as células FR apresentaram uma expressão de Sf-1 significantemente maior ( $0.95 \pm 0.32 ; \mathrm{p}=0.0219)$, em relação às células G.

Figura 6 - Expressão relativa de do gene Sf-1

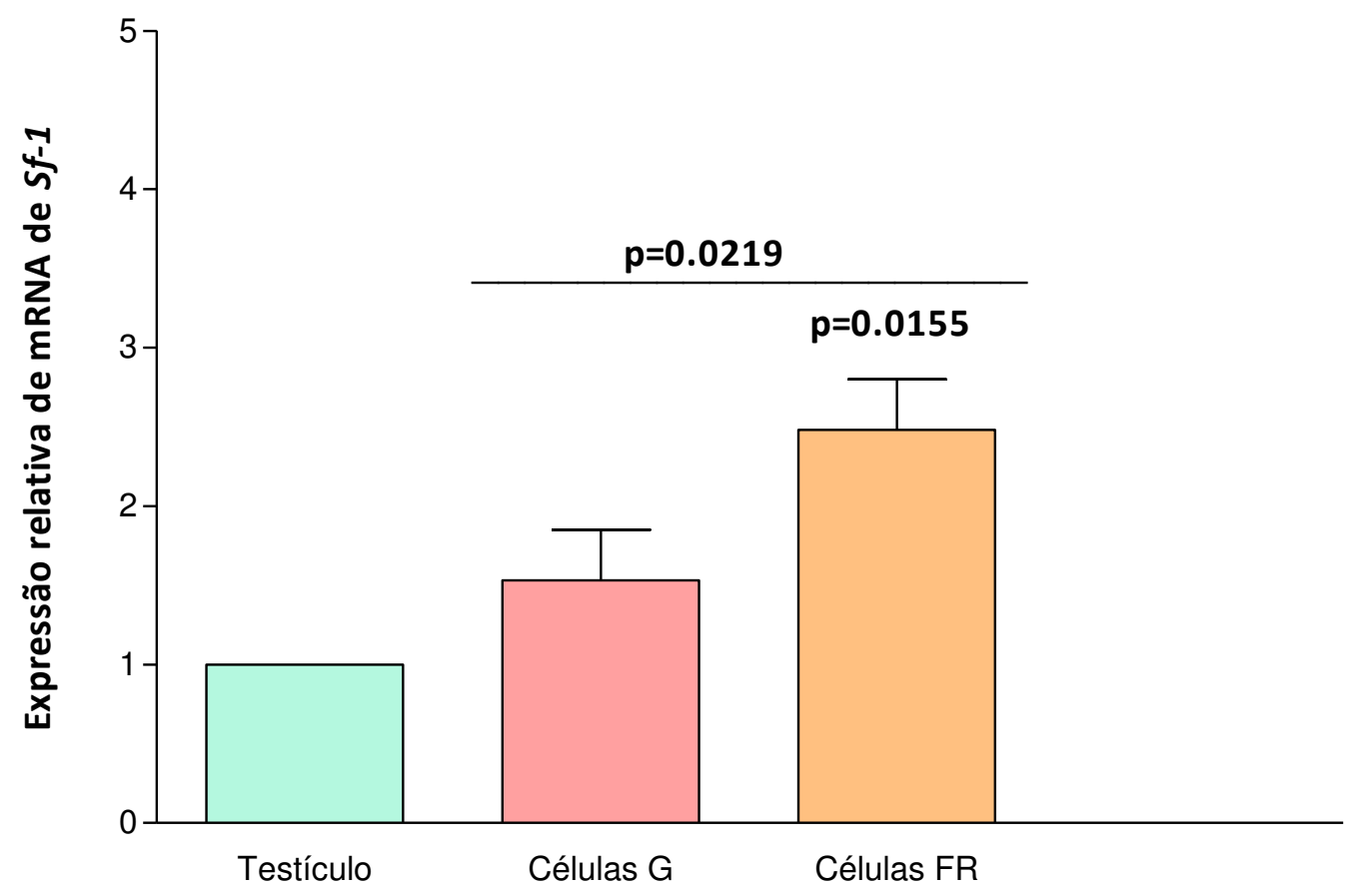

Análise da expressão relativa do gene Sf-1 nas células da Glomerulosa (células G), nas células da Fasciculada e Reticulada (células FR) e no Testículo (controle). Testículo vs células FR p=0.0155; células $G$ vs células $F / R$ p=0.0219. $n=3$ 


\subsection{Imunolocalização da proteína SF-1 no córtex da adrenal de rato.}

O resultado da imunolocalização de SF-1 mostrou que essa proteína está expressa nas três zonas do córtex adrenal, zona Glomerulosa, Fasciculada e Reticulada, mas não está expressa na cápsula nem na medula.

Figura 7 - Expressão proteica de SF-1 na adrenal de rato

A

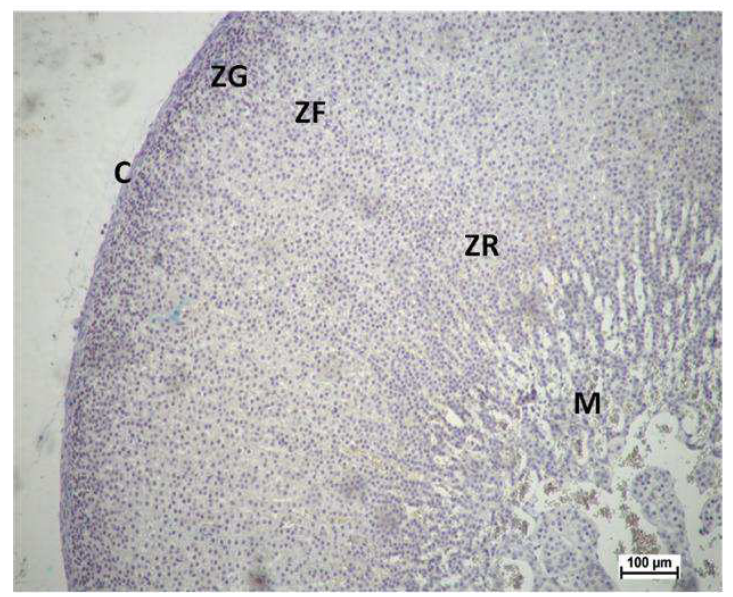

B

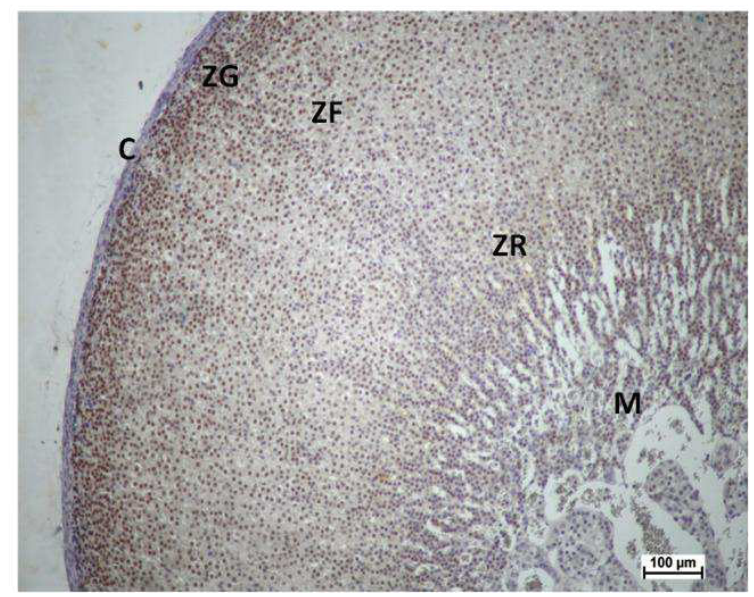

Imunolocalização da proteína $\mathrm{SF}-1$ na adrenal de rato $\mathrm{C}=$ capsula; $\mathrm{ZG}=$ zona glomerulosa; $\mathrm{ZF}=$ zona fasciculada; $\mathrm{ZR}=$ zona reticulada; $M=$ medula. (A) Controle (sem o anticorpo anti-NR5A1), (B) (com anti- NR5A1). $n=3$ 


\subsection{Análise da expressão do gene Pod-1 nas células do córtex adrenal}

Os resultados da expressão de Pod-1 mostraram que, em relação à expressão de Pod-1 obtida a partir do mRNA de pulmão, que expressa esse gene de maneira constitutiva Quaggin et al. (1999), as células G e FR apresentaram uma expressão baixa desse gene, respectivamente $0.0010 \pm 0.0006$ e $0.0006 \pm 0.0001$ (Figura 8). A comparação entre as células G e FR quanto à expressão do gene Pod-1 não apresentou diferenças estatisticamente significantes.

Figura 8 - Expressão relativa Pod-1

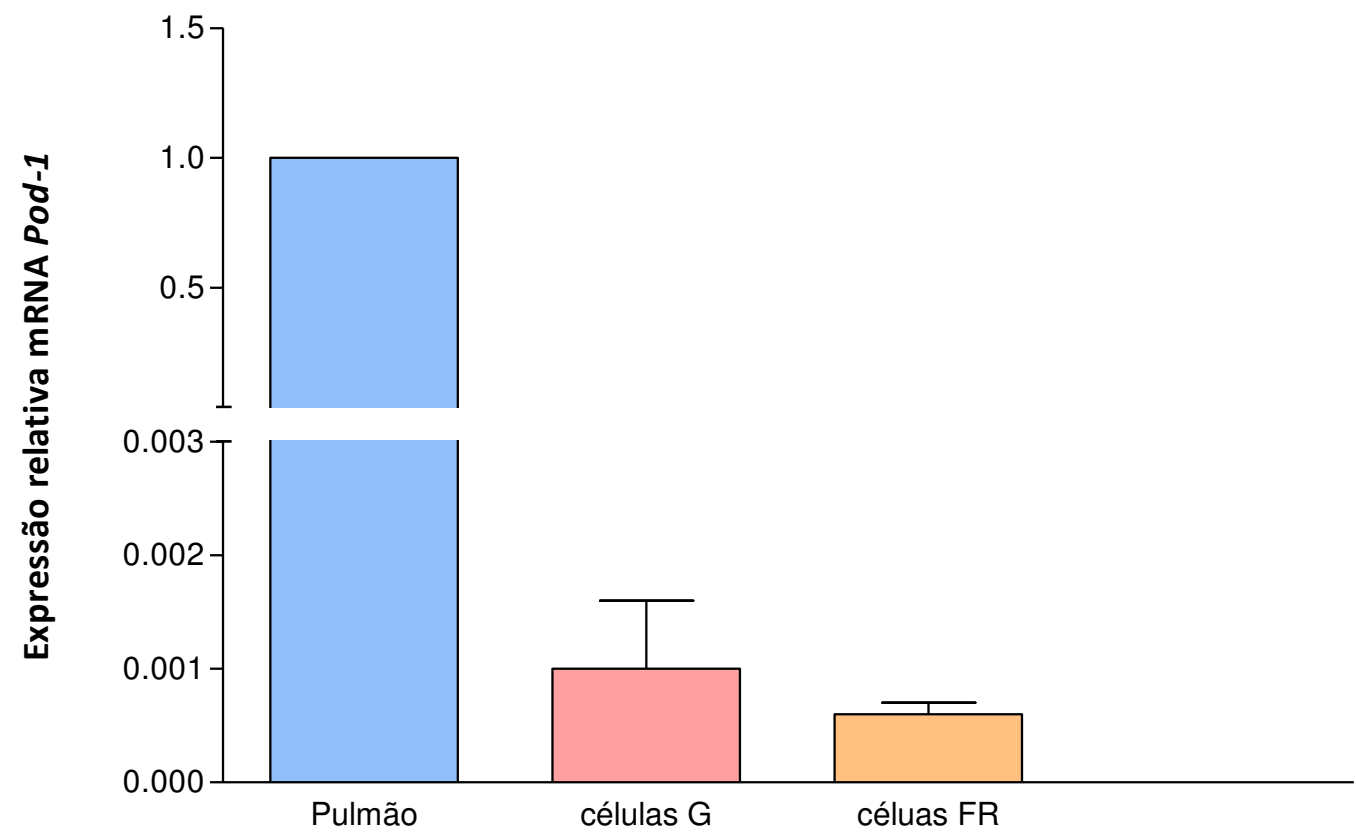

Análise da expressão relativa do gene Pod-1 nas células da Glomerulosa (células G), nas células da Fasciculada e Reticulada (células FR) e no Pulmão (controle). n=3 
4.4 Análise do gene Pod-1 em culturas primárias das células G e FR transfectadas com os plasmídeos CMVMyc e CMVMycPod-1

Os resultados da expressão de Pod-1 nas células G e FR mostraram que ambos os tipos celulares foram eficientemente transfectados com o pCMVMycPod-1. As células apresentaram hiperexpressão do gene Pod-1, respectivamente de $26.581 \pm 6.668$ FR e $466.585 \pm 144.168$ vezes nas células G (Figura 9A) e nas células FR (Figura 9B), em relação à transfecção com o vetor vazio. 
Figura 9 - Expressão relativa do gene Pod-1
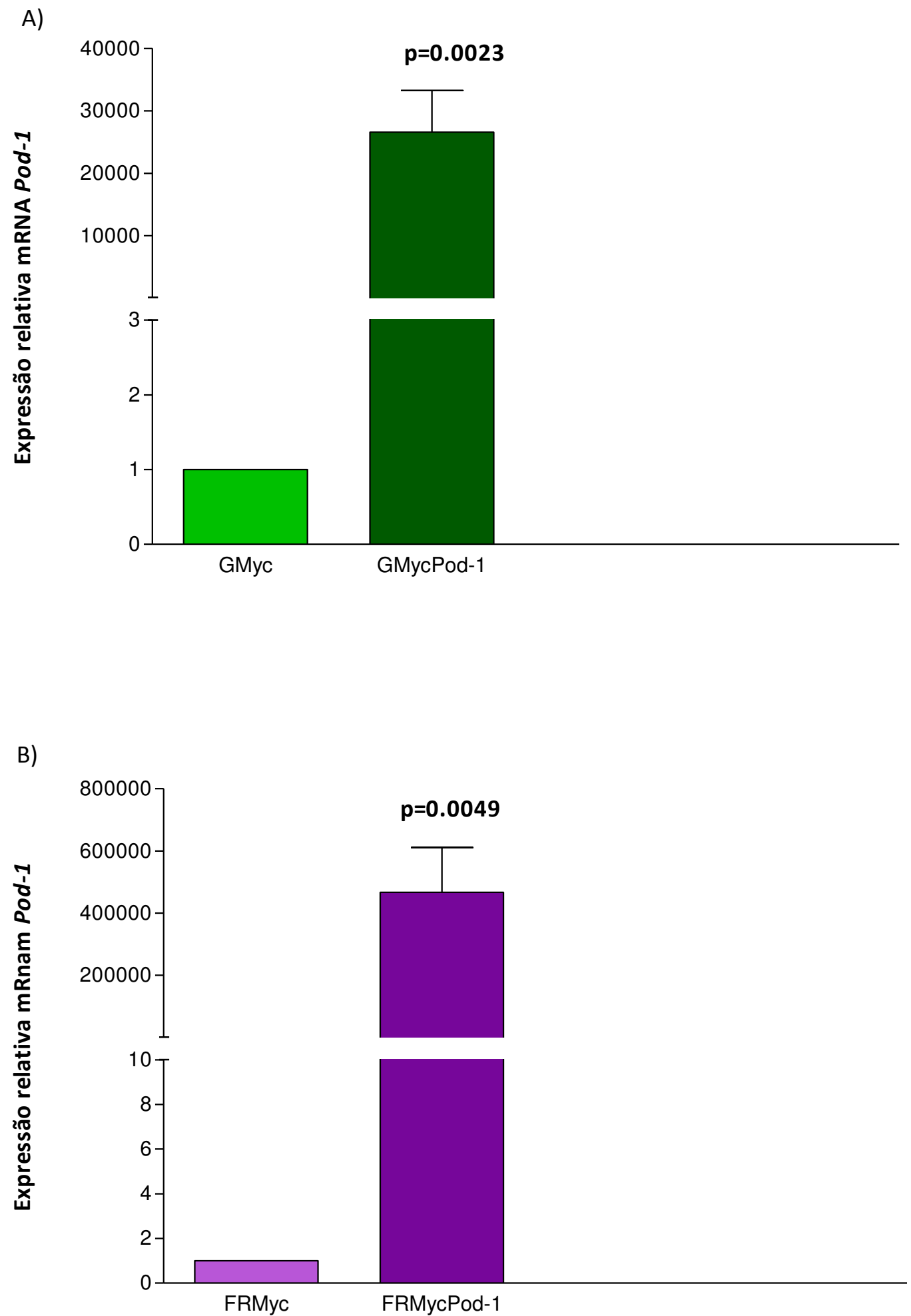

Análise da expressão relativa do gene Pod-1 nas células da Glomerulosa e nas células da Fasciculada e Reticulada, transfectadas com pCMVMyc (respectivamente, GMyc e FRMyc) e com pCMVMycPod-1(respectivamente, GMycPod1 e FRMycPod-1).GMyc vs GMycPod-1 p= 0.0023, FRMyc vs FRMycPod-1. $n=3$ 


\subsection{Análise da expressão da proteína POD-1 nas culturas primárias transfectadas com os plasmídeos CMVMyc e CMVMyc-Pod-1}

Através da análise da expressão relativa da proteína Myc, que foi utilizada como “Tag”, foi detectada a expressão do produto proteico da hiperexpressão do gene Pod-1 (Figura 10). A expressão basal da proteína Myc é mais baixa nas células G (Figura 10A) que nas células FR (Figura 10B), no entanto ambas as culturas apresentaram aumento estatisticamente significante da expressão da proteína Myc, após a transfecção com os plasmídeos pCMVMyc (respectivamente, p=0.049 e p=0.047) e pCMVMycPod1 ( $p=0.025$ e $\mathrm{p}=0.046$ ). Contudo não houve diferença estatisticamente significante entre a expressão de Myc entre as células $\mathrm{G}$ ( $\mathrm{p}=0.36$; Figura 10A) e as células FR transfectadas ( $\mathrm{p}=0.50$; Figura 10B). O aumento da expressão da proteína Myc sugere que a proteína Pod-1 foi expressa em ambos os tipos celulares transfectados. 
Figura 10 - Expressão da proteína c-Myc

A)

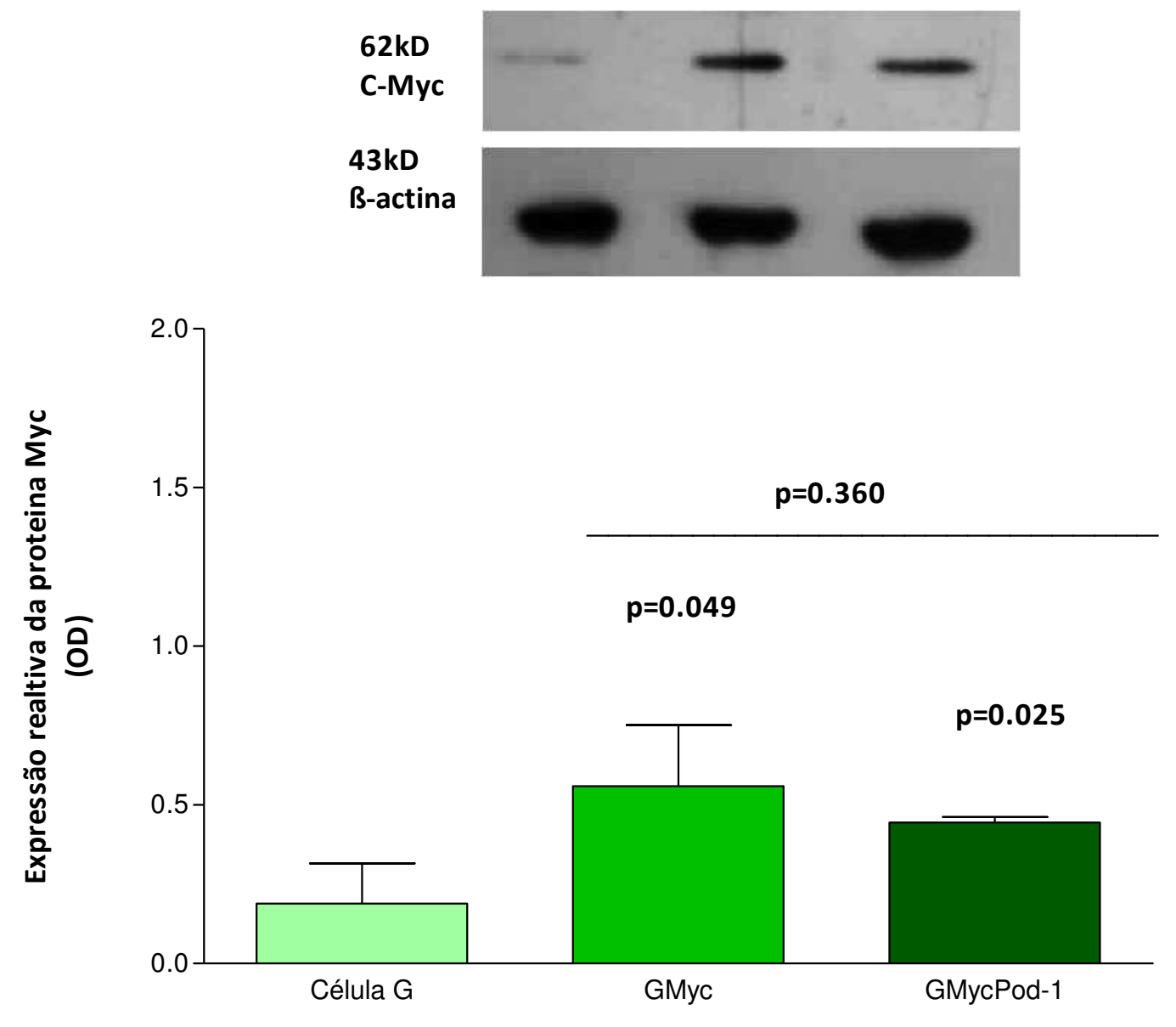


B)

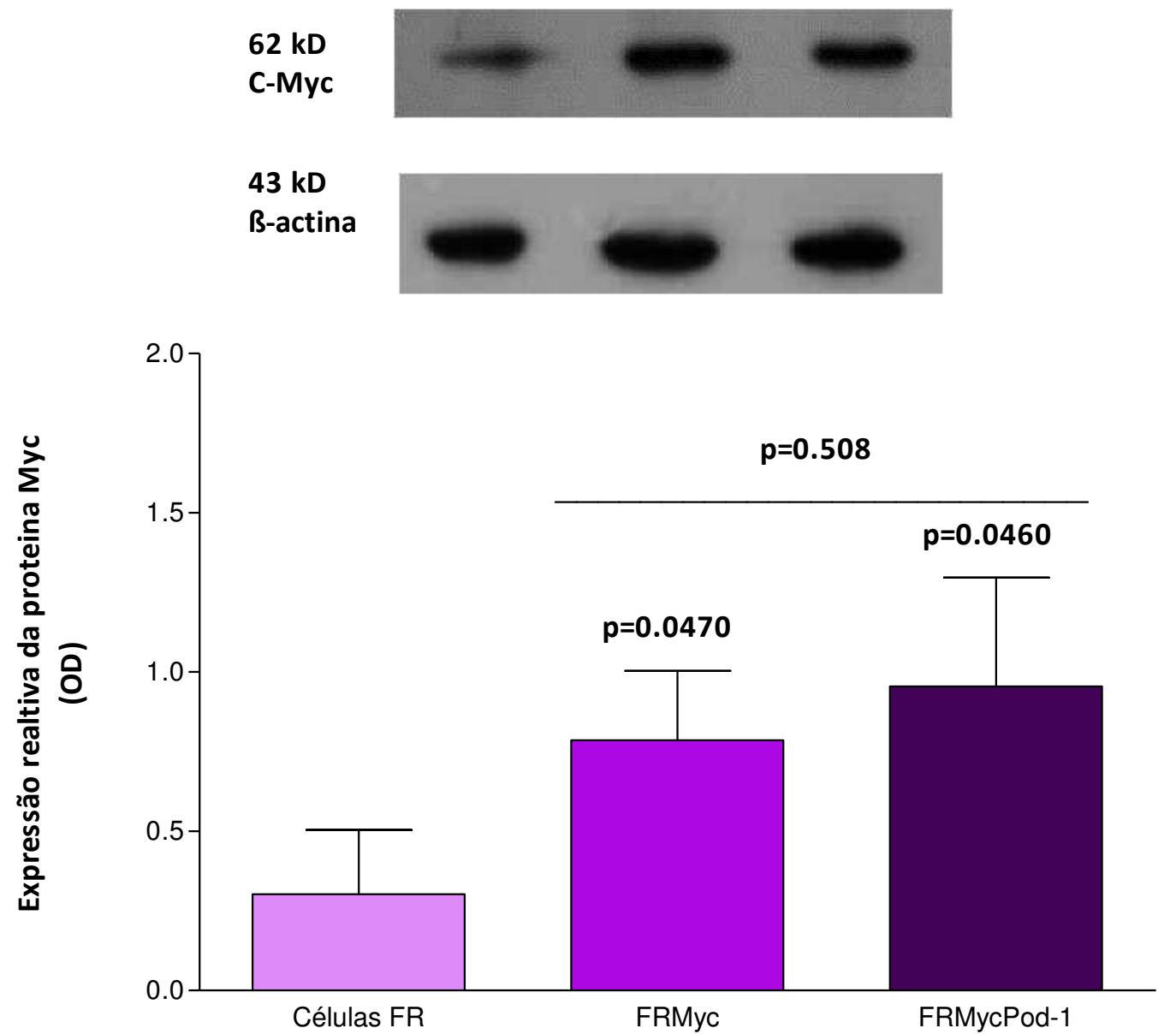

Análise da expressão relativa da proteína Myc nas células da Glomerulosa e nas células da Fasciculada e Reticulada, transfectadas com pCMVMyc (respectivamente, GMyc e FRMyc) e com pCMVMycPod-1(respectivamente, GMycPod1 e FRMycPod-1). n=3 
4.6 Análise da expressão do gene $\mathrm{Sf}-1$ nas culturas primárias das células $\mathrm{G}$ e F/R transfectadas com os plasmídeos CMVMyc e CMVMycPod-1.

A expressão do gene $\mathrm{Sf}-1$ foi avaliada nas células $\mathrm{G}$ e $\mathrm{F} / \mathrm{R}$ transfectadas transientemente com o plasmídeo CMVMycPod-1. Os resultados mostraram que as células G transfectadas com o gene Pod-1 não apresentaram alteração estatisticamente significante $(\mathrm{p}=0.15)$ da expressão do gene Sf-1 (Figura 11). Por outro lado, as células FR transfectadas com o gene Pod-1 apresentaram aumento significante da expressão de Sf-1 ( $\mathrm{p}=0.048)$.

Figura 11 - Expressão relativa do gene Sf-1

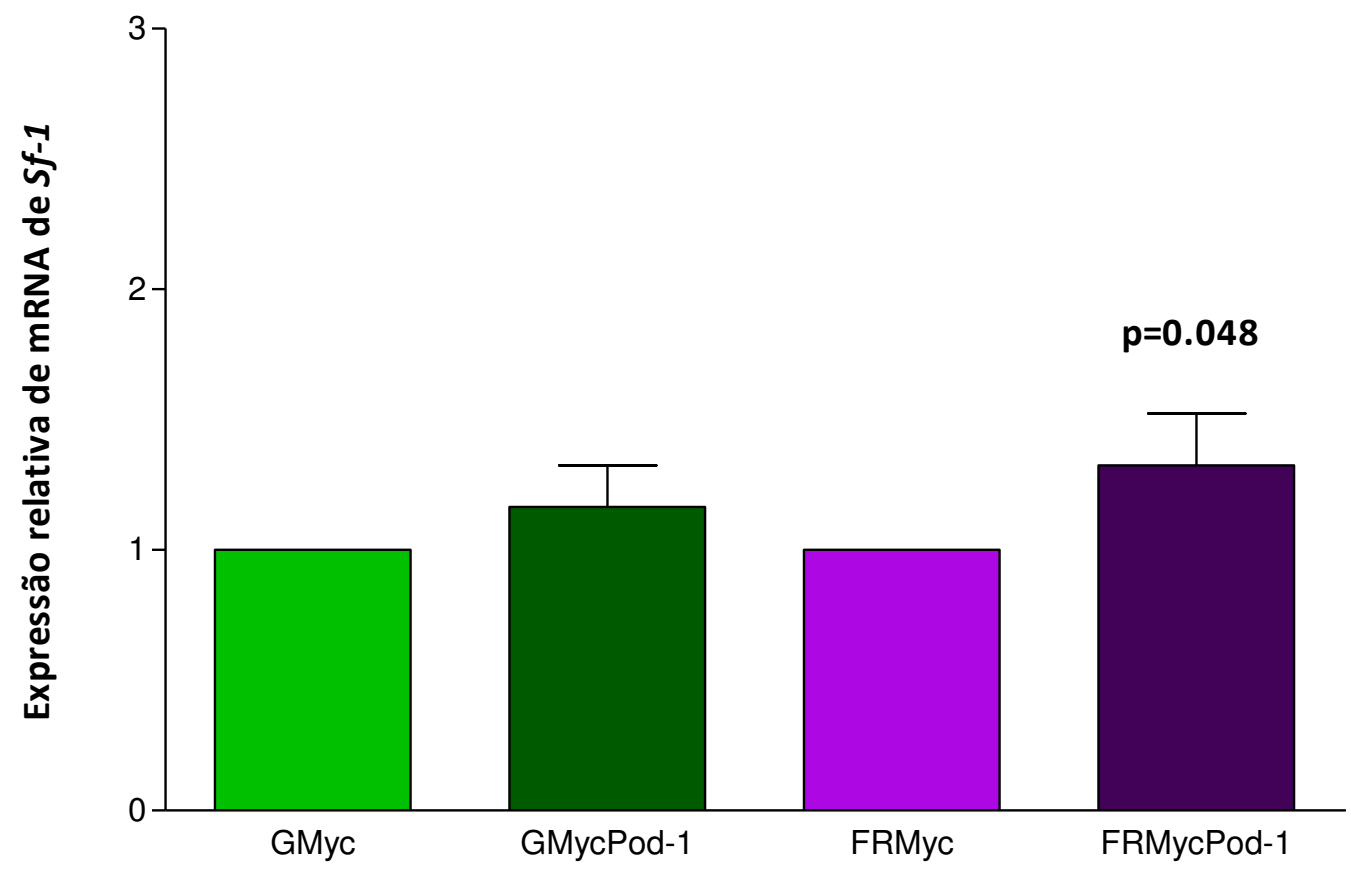

Análise da expressão relativa do gene Sf-1 nas células da Glomerulosa e nas células da FR transfectadas com pCMVMyc (GMyc e FRMyc) e com pCMVMycPod-1(GMycPod1 e FRMycPod-1). FRMyc vs FRMycPod-1 ( $\mathrm{p}=0.048) . \mathrm{n}=3$ 
5 DISCUSSÃO 
SF-1 ou NR5A1 é um membro da família de receptores nucleares que exerce um papel importante no desenvolvimento, na regulação e na função dos tecidos esteroidogênicos (LALA et al., 1992). A expressão de Sf-1 é detectada durante o desenvolvimento embriológico no primórdio adrenogonadal (AGP) em torno da idade embrionária E9 em camundongos, e E11.5 em ratos. No momento em que ocorre a separação do AGP, Sf-1 é expresso em ambas as populações celulares das gônadas e das suprarrenais, e permanece expresso ao longo do desenvolvimento adrenal. Quando o córtex e a medula da suprarrenal se formam, a expressão de Sf-1 permanece na região do córtex (HATANO et al., 1994, 1996). Esse fator de transcrição tem um papel regulador na ativação de alguns genes em órgãos alvos como os testículos, ovários e as glândulas suprarrenais. No testículo, SF-1 é importante para o desenvolvimento e para a manutenção do fenótipo masculino (TREMBLAY et al., 2005; ZIMMERMANN et al., 1998). No ovário, a expressão de SF-1 é essencial para o seu desenvolvimento e importante para o seu funcionamento apropriado, pois está envolvido na esteroidogênese ovariana (MŁYNARCZUK; RĘKAWIECKI, 2010).

A expressão de SF-1 na glândula suprarrenal, durante a fase adulta, mostrou-se semelhante entre as espécies. Em bovinos, a expressão de SF-1 permanece quase uniforme em todo córtex (MOROHASHI et al., 1995). Nos ratos adultos, a expressão de SF-1 no córtex adrenal ocorre sem diferenciação zonal, embora a sua expressão sofra certa diminuição após tratamento com ACTH (RAZA; PUDDEFOOT; VINSON, 1998). A mesma análise mostrou resultados semelhantes em humanos, independente se em córtex normal ou em alguma patologia (SASANO et al., 1995). Esses resultados estão de acordo com o observado nos ensaios de imunoperoxidase apresentados, quando não foi observada uma diferença zonal da expressão de SF-1 ao longo do córtex adrenal de ratos. Por outro lado, a análise da expressão gênica de Sf-1 mostrou que existe diferença entre a expressão do gene Sf-1 nas células da Glomerulosa e nas células da Fasciculada/Reticulada, quando isoladas em cultura. Entretanto essa diferença de expressão não se reflete na análise por imunoperoxidase realizada na glândula in vivo, pois não foi observada diferença entre as zonas analisadas. Essa análise não é apropriada para uma análise quantitativa, mas qualitativa e de localização das células que expressam a proteína.

O fator de transcrição SF-1 pode ser reconhecido por fatores de transcrição da família bHLH, entre eles, POD-1 (CUI et al., 2004; TAMURA et al., 2001). Análise da hiperexpressão de Pod-1 em células de Lyedig originárias de testículos de camundongo, linhagem MA-10, mostrou inibição da expressão de Sf-1 (CUI et al., 2004). Além disso, esse trabalho sugere que o mecanismo de inibição de Sf-1 ocorre devido à ligação de Pod-1 à 
região E-box do promotor de Sf-1 (CUI et al., 2004). Para que isso ocorra, Pod-1 parece antagonizar com o fator de transcrição Upstream Stimulatory Factor (USF), uma proteína bHLH envolvida na transcrição basal de Sf-1 por ligação no sitio E-box do seu promotor (CUI et al., 2004; HARRIS; MELLON, 1998).

Na glândula suprarrenal de camundongos modificados Pod-1/LacZ, a expressão de POD-1 foi localizada e restrita à capsula. Por outro lado, a expressão de POD-1 não foi observada na cápsula de camundongos POD- ${ }^{-/}$, enquanto a expressão de SF-1 foi restrita ao córtex adrenal. No entanto, em camundongos heterozigotos POD- $1^{+/-}$, observou-se, durante o desenvolvimento desses animais, um aumento de células SF-1 positivas na região da capsula, o que reforça o papel de POD-1 como inibidor da expressão de SF-1 (KIM et al., 2009). Os resultados da expressão gênica de Sf-1 nas culturas primárias do córtex adrenal de rato mostraram que existe uma diferença significativa na expressão desse fator de transcrição entre as células isoladas da Glomerulosa e da Fasciculada/Reticulada, de maneira que as células F/R apresentaram uma expressão maior de $\mathrm{Sf}-1$ do que as células $\mathrm{G}$, embora a imunolocalização não corrobore esse fato. Quanto à expressão endógena de Pod-1, essa não apresenta diferença significativa entre as células $\mathrm{G}$ e $\mathrm{F} / \mathrm{R}$ e é muito baixa em ambos os tipos celulares. Através dos resultados obtidos no sistema de cultura de células primárias adrenais isoladas, portanto, não podemos sugerir se há relação entre a expressão de Sf-1 e a de Pod-1.

Em tumores humanos, como os de cabeça e pescoço, pulmão e em melanomas, POD-1 é pouco expresso e nos carcinomas de células escamosas de cabeça e pescoço, a expressão proteica e o nível de metilação de promotor de POD-1 são candidatos a biomarcadores desse tipo de tumor (ARAB et al., 2011; GIORDANO et al., 2009; SMITH et al., 2006; WEISS et al., 2013).

Amostras de adrenais normais, de adenomas e de carcinomas adrenocorticais de pacientes foram analisadas em um ensaio de "microarray" realizado pelo grupo de Michigan, no qual se constatou que POD-1 está mais expresso nas amostras de adrenais normais quando comparadas com as amostras de tumores adrenocorticais. Esses dados foram validados pelo nosso grupo em um estudo in vitro utilizando células de carcinomas adrenocorticais que mostraram que a expressão de SF-1 e de algumas enzimas esteroidogênicas são inibidas quando POD-1 está hiperexpresso nessas células (FRANÇA et al., 2013).

A análise da transfecção das culturas de células com o plasmídeo CMVMycPod-1 por PCR quantitativo mostrou que as células F/R apresentaram uma hiperexpressão de Pod-1 de cerca de quinze vezes mais do que as células G, o que sugere uma eficiência de transfecção maior nas células F/R que nas células G. Quando as células transfectadas com Pod-1 foram 
analisadas quanto à expressão gênica de $\mathrm{Sf}-1$, os resultados mostraram que as células G não apresentaram alteração da expressão endógena de Sf-1. Todavia as células F/R transfectadas com Pod-1 apresentaram um aumento da expressão de Sf-1, em contraste com o observado, até então, na literatura, que mostra que POD-1 é fator de transcrição que inibe a expressão de Sf-1 (CUI et al., 2004; HARRIS; MELLON, 1998). O fato de somente as células F/R apresentarem alteração dos níveis de Sf-1 endógeno pode estar relacionado com o nível de hiperexpressão obtido nesses tipos celulares, que foi diferente do observado nas células G. Concluindo, podemos sugerir que as células normais do córtex adrenal em cultura apresentam mecanismos ainda não conhecidos de regulação de Sf-1, através de Pod-1. Uma investigação dos mecanismos da ação de Pod-1 e dos efeitos biológicos da modulação da expressão de Sf-1 nas culturas primárias de células adrenocorticais de rato estão em andamento. 


\section{CONCLUSÕES}


- O gene Sf-1 está mais expresso nas células que compõem as zonas mais internas do córtex adrenal de rato, células da Fasciculada/Reticulada, do que nas células Glomerulosas, que compõem a zona mais externa;

- A variação da expressão gênica de Sf-1 em cultura não parece estar refletida na expressão da proteína SF-1, uma vez que, pelo método de imunoistoquímica, não observamos diferença zonal de SF-1;

- O gene Pod-1 endógeno está pouco e similarmente expresso nas células em cultura da Glomerulosa e Fasciculada/Reticulada de adrenal de rato;

- A hiperexpressão do fator de transcrição Pod-1 aumenta a expressão do gene Sf-1 endógeno nas culturas de células da Fasciculada/Reticulada, mas não tem efeito nas células da Glomerulosa;

- Nossos resultados sugerem mecanismos distintos de controle da expressão de Sf-1 pelo fator de transcrição POD-1/TCF21, em células adrenais normais de rato e em células de tumores adrenocorticais. 


\section{REFERÊNCIAS}




\section{REFERÊNCIAS*}

ALMEIDA, M. Q.; SOARES, I. C.; RIBEIRO, T. C.; FRAGOSO, M. C.; MARINS, L. V.; WAKAMATSU, A.; RESSIO, R. A.; NISHI, M. Y.; JORGE, A. A.; LERARIO, A. M.; ALVES, V. A.; MENDONCA, B. B.; LATRONICO, A. C. Steroidogenic factor 1 overexpression and gene amplification are more frequent in adrenocortical tumors from children than from adults. J. Clin. Endocrinol. Metab., v. 95, p. 1458-1462, 2010.

ARAB, K.; SMITH, L. T.; GAST, A.; WEICHENHAN, D.; HUANG, J.; CLAUS. R.; HIELSCHER, T.; ESPINOSA, A. V.; RINGEL. M. D.; MORRISON, C. D.; SCHADENDORF, D.; KUMAR, R.; PLASS, C. Epigenetic deregulation of TCF21 inhibits metastasi suppressor KISS1 in metastic melanoma. Carcinogenesis., v. 32, p. 1467-1473, 2011.

BARNHART, K. M.; MELLON P. L. The orphan nuclear receptor, steroidogenic factor-1, regulates the glycoprotein hormone alpha-subunit gene in pituitary gonadotropes. Mol. Endocrinol., v. 8, p 878-885, 1994.

BLAND, M. L.; JAMIESON, C. A.; AKANA, S. F.; BORNSTEIN, S. R.; EISENHOFER, G.; DALLMAN, M. F.; INGRAHAM, H. A. Haploinsufficiency of steroidogenic factor-1 in mice disrupts adrenal development leading to an impaired stress response. Proc Natl Acad Sci. USA., v. 97, n. 26, p. 14488-14493, 2000.

CLEMENS, J. W.; LALA, D. S.; PARKER, K. L.; RICHARDS, J. S. Steroidogenic factor-1 binding and transcriptional activity of the cholesterol side-chain cleavage promoter in rat granulosa cells. Endocrinology, v. 134, p. 1499-1508, 1994.

CRAWFORD, P. A.; DORN, C.; SADOVSKY, Y.; MILBRANT, J. Nuclear receptor DAX-1 recruits nuclear receptor corepressor N-Cor to steroidogenic factor 1. Mol. Cell. Biol., v. 18, p. 2949-2956, 1998.

CUI, S.; ROSS, A.; STALlingS, N.; PARKER, K. L.; CAPEL, B.; QUAGGIN, S. E. Disrupted gonadogenesis and male-to-female sex reversal in Pod1 knockout mice. Development, v. 131, p. 4095-4105, 2004.

DAGGETT, M. A.; RICE D. A.; HECKER, L. L. Expression of steroidogenic factor 1 in 433 the testis requires an E box and CCAAT box in its promoter proximal region 434. Biol. Reprod., v. 62, p. 670-679, 2000.

DÂNGELO, J. G.; FATTINI C. A. Anatomia humana sistêmica e segmentar. 3. ed. São Paulo: Atheneu, 2007.

DOGHMAN, M.; KARPOVA, T.; RODRIGUES, G. A.; ARHATTE, M.; DE MOURA, J.; CAVALLI, L. R.; VIROLLE, V.; BARBRY, P.; ZAMBETTI, G. P.; FIGUEIREDO, B. C.; HECKERT, L. L.; LALLI, E. Increased steroidogenic factor-1 dosage triggers adrenocortical cell proliferation and cancer. Mol. Endocrinol., v. 21, p. 2968-2987, 2007.

\footnotetext{
*De acordo com: ASSOCIAÇÃO BRASILEIRA DE NORMA TÉCNICAS. NBR 6023: informação e documentação: referências: elaboração. Rio de janeiro, 2002.
} 
FIGUEIREDO, B. C.; CAVALLI, L. R.; PIANOVSKI, M. A.; LALLI, E.; SANDRINI, R.; RIBEIRO, R.C.; ZAMBETTI, G.; DELACERDA, L.; RODRIGUES, G. A.; HADDAD B. R. Amplification of the steroidogenic factor-1 gene in childhood adrenocortical tumors. J. Clin. Endocrinol. Metab., v. 90, p. 615-619, 2005.

FUNATO, N.; OHYAMA, K.; KURODA. T.; NAKAMURA, M. Basic helix-loop-helix transcription factor epicardin/capsulin/pod-1 suppresses differentiation by negative regulation of transcription. JBC, v. 278, p. 7486-7493, 2003.

FRANÇA, M. M.; FERRAZ-DE-SOUZA, B.; SANTOS, M. G.; LERARIO, A. M.; FRAGOSO, M. C.; LATRONICO, A. C.; KUICK, R. D.; HAMMER, G. D.; LOTFI, C. F. POD-1 binding to the E-box sequence inhibits SF-1 and StAR expression in human adrenocortical tumor cells. Mol. Cell. Endocrinol., v. 371, n. 1-2, p. 140-147, 2013.

FRIGERI, C.; TSAO, J.; CZERWINSKI, W.; SCHIMMER, B. P. Impaired steroidogenic factor 1 (NR5A1) activity in mutant Y1 mouse adrenocortical tumor cell. Mol. Endocrinol., v. 14 , p. $535-544,2000$.

GALLO-PAYET, N.; CHOUINARD, L.; BALESTRE, M. N.; GUILLON, G. Dual effects of dopamine in rat adrenal glomerulosa cells. Biochem. Biophys. Res. Commun., v. 172, p. 1100-1108, 1990.

GIORDANO, T. J.; KUICK, R.; ELSE, T.; GAUGER, P. G.; VINCO, M.; BAUERSFELD, J.; SANDERS, D.; THOMAS, D. G.; DOHERTY, G.; HAMMER, G. D. Molecular classification and prognostication of adrenocortical tumors by transcriptome profiling. Clin. Cancer Res., v. 15, p. 668-676, 2009.

GOSS, M. C. Gray anatomia. 29. ed. Rio de Janeiro: Guanabara Koogan, 1998.

HANLEY, N. A.; BALL, S. G.; CLEMENT-JONES, M.; HAGAN, D. M.; STRACHAM, T.; LINDSAY, S.; ROBSON, S.; OSTRER, H.; PARKER, K. L.; WILSON, D. I. Expression steroidogenic factor-1 and Wilms` tumor 1 during early human gonadal development and sex determination. Mech. Dev., v. 87, p. 175-180, 1999.

HATANO, O.; TAKAYAMA, K.; IMAI, T.; WATERMAN, M. R.; TAKAKUSU, A.; OMURA, T.; MOROHASHI, K. Sex-dependent expression of a transcription factor, Ad4BP, regulating steroidogenic $\mathrm{P}-450$ genes in the gonads during prenatal and postnatal rat development. Development, v. 120, p. 2787-2797, 1994.

HATANO, O.; TAKAKUSU, A.; NOMURA, M.; MOROHASHI, K. Identical origin of adrenal cortex and gonad revealed by expression profiles of Ad4BP/SF-1.Genes Cells, v. 1, p. 663-671, 1996.

HARRIS, A. N.; MELLON, P. L. The basic helix-loop-helix, leucine zipper transcription factor, USF (upstream stimulatory factor), is a key regulator of SF-1 (steroidogenic factor-1) gene expression in pituitary gonadotrope and steroidogenic cells. Mol. Endocrinol., v.12, p. 714-726, 1998.

HEBEL, R.; STROMBER, M. W. Anatomy and embryology of the laboratory rat. Germany: BioMed Verlag, 1986. 
HONDA, S.; MOROHASHI, K.; NOMURA, M.; TAKEYA, H.; KITAJIMA, M.; OMURA, T. Ad4BP regulating steroidogenic P-450 gene is a member of steroid hormone recepter superfamily. J. Biol. Chem., v. 268, p. 7494-7502, 1993.

IKEDA, Y.; LALA, D. S.; LUO, X.; KIM, E.; MOISAN, M. P.; PARKER, K. L. Characterization of the mouse FTZ-F1 gene, which encodes a key regulator of steroid hydroxylase gene expression. Mol. Endocrinol., v. 7, p. 852-860, 1993.

IKEDA, Y.; SWAIN, A.; WEBER, T. J.; HENTGES, K. E.; ZANARIA, E.; LALLI, E.; TAMAI, K. T.; SASSONE-CORSI, P.; LOVELL-BADGE, R.; CAMERINO, G.; PARKER, K. L. Steroidogenic factor-1 and Dax-1 colocalize in multiple cell lineages: potential links in endocrine development. Mol. Endocrinol., v. 10, p. 1261-1272, 1996.

INGRAHAM, H. A.; LALA, D. S.; IKEDA, Y.; LUO, X.; SHEN, W. H.; NACHTIGAL, M. W.; ABBUD, R.; NILSON, J. H.; PARKER, K. L. The nuclear receptor steroidogenic factor 1 acts at multiple levels of the reproductive axis. Gene Dev., v. 8, p. 2302-2312, 1994.

ITO, M.; YU, R.; JAMESON, J. L. DAX-1 inhibits SF-1 mediated transactivation via a carboxy terminal domain that is deleted in adrenal hypoplasia congenital. Mol. Cell. Biol., v. 17, n. 3, p. 1476-1483, 1997.

JUNQUEIRA, L. C. U.; CARNEIRO, J. Histologia básica. 10. ed. Rio de Janeiro: Guanabara Koogan, 2004.

KADESCH, T. Consequences of heteromeric interactions among helix-loop-helix proteins. Cell Growth Differ., v. 4, p. 49-55, 1993.

KIM, A. C.; BARLASKAR, M. F. In search of adrenocortical stem and progenitor cells. Endocrine Reviews, v. 30, n. 3, p. 241-263, 2009.

LALA, D. S.; RICE, D. A.; PARKER, K. L. Steroidogenic factor 1, a key regulator of steroidogenic enzyme expression, is the mouse homolog of fushi tarazu-factor I. Mol. Endocrinol., v. 6, p. 1249-1258, 1992.

LAVORGMA, G.; UEDA, H.; CLOS, J.; WU, C. FTZ-F1, a steroid hormone receptor-like protein implicated in the activation of fushi tarazu. Science, v. 252, p. 848-851, 1992.

LIVAK, K. J.; SCHMITTGEN, T. D. Analysis of relative gene expression data using real time quantitative PCR and the $2^{-\Delta \Delta C t}$ Method. Methods, v. 25, p. 4002-4080, 2001.

LU, J.; RICHARDSON, J. A.; OLSON, E. N. Capsulin: a novel bHLH transcription factor expressed in epicardial progenitors and mesenchyme of visceral organs. Mech. Dev., v. 73, p. 23-32, 1998.

LU T. T.; MAKISHIMA, M.; REPA, J. J.; SCHOONJANS, K.; KERR, T. A.; AUWERX, J.; MANGELSDORF D. J. Molecular basis for feedback regulation of bile acid synthesis by nuclear receptor. Mol. Cell, v. 6, p. 507-515, 2000. 
LUO, X.; IKEDA, Y.; PARKER, K. L. A cell-specific nuclear receptor is essential for adrenal and gonodal development and sexual differentiation. Cell, v. 77, p. 481-490, 1994.

MASSARI, M. E.; MURRE, C. Helix-Loop-Helix proteins: regulators of the transcription in eucaryotic organisms. Mol. Cell Biology, v. 20, p. 429-440, 2000.

MARCHAL, R.; NAVILLE, D.; DURAND, P.; BEGEOT, M.; PENHOAT, A. A steroidogenic factor-1 binding element is essential for basal human ACTH receptor gene transcription. Biochem. Biophys. Res. Commum., v. 247, p. 28-32, 1998.

MŁYNARCZUK, J.; RĘKAWIECKI, R. The role of the orphan receptor SF-1 in the development and function of the ovary. Reprod. Biol., v. 10, n. 3, p. 177-193, 2010.

MOORE, K. L. Anatomia orientada para clínica. 3. ed. Rio de Janeiro: Guanabara Koogan, 1994.

MOROHASHI, K.; IIDA, H.; NOMURA, M.; HATANO, O.; HONDA, S.; TSUKIYAMA, T.; NIWA, O.; HARA, T.; TAKAKUSU, A.; SHIBATA, Y. Functional difference between Ad4BP and ELP, and their distributions in steroidogenic tissues. Mol. Endocrinol., v. 8, p. 643-653, 1994.

MOROHASHI, K.; HATANO, O.; NOMURA, M.; TAKAYAMA, K.; HARA, M.; YOSHII, H.; TAKAKUSU, A.; OMURA, T. Function and distribution of a steroidogenic cell-specific transcription factor, Ad4BP. J. Steroid. Biochem. Mol. Biol., v. 53, p. 81-88, 1995.

MOROHASHI, K.; TSUBOI-ASAI, H.; MATSUSHITA, S.; SUDA, M.; NAKASHIMA, M.; SASANO, H.; HATABA, Y.; LI, C. L.; FUKATA, J.; IRIE, J.; WATANABE, T.; NAGURA, H.; LI, E. Structural and functional abnormalities in the spleen of na mFtz-F1 gene disrupted mouse. Blood, v. 93, p. 1586-1594, 1999.

MATTOS, G. E.; LOTFI, C. F. Differences between the growth regulatory pathways in primary rat adrenal cells and mouse tumor cell line. Molecular and Cellular Endocrinology, v. 24, n. 1-2, p. 31-42, 2005.

MATTOS, G.; JACYSYN, J.; AMARANTE-MENDES, G.; LOTFI, C. Comparative effect of FGF2, synthetic peptides 1-28 N-POMC and ACTH on proliferation in rat adrenal cell primary cultures. Cell and Tissue research, v. 345, p. 343-356, 2011.

NAVILLE, D.; PENHOAT, A.; MARCHAL, R.; DURAND, P.; BEGEOT, M. SF-1 and the transcriptional regulation of the human ACTH receptor gene. Endocr. Res., v. 24, p. 391395, 1998.

NAVILLE D., PENHOAT A., MARCHAL R., DURAND P., BEGEOT M. Three steroidogenic factor-1 binding elements are required for constitutive and cAMP-regulated expression of the human adrenocorticotropin receptor gene. Biochem. Biophys. Res. Commum., v. 255, p. 28-33, 1999.

NETTER, F. H. Atlas de anatomia humana. 4. ed. Rio de Janeiro: Elsevier, 2008. 
NOMURA, M.; BARTSCH, S.; NAWATA, H.; OMURA, T.; MOROHASHI, K. In the E box element is required for the expression of the ad4bp gene, a mammalian homologue of ftzf1 gene, which is essential for adrenal and gonadal development. J. Biol. Chem., v. 270, p. 7453-7461, 1995.

PIANOVSKI, M. A.; CAVALLI, L. R.; FIGUEIREDO, B. C.; SANTOS, S. C.; DOGHMAN, M.; RIBEIRO, R. C.; OLIVEIRA, A. G.; MICHALKIEWICZ, E.; RODRIGUES, G. A.; ZAMBETTI, G.; HADDAD, B. R.; LALLI, E. SF-1 overexpression in childhood adrenocortical tumours. Eur. J. Cancer., v. 42, p. 1040-1043, 2006.

POPESKO, P.; REJTOVÁ, V.; HORAK, J. A. Colour atlas of the anatomy of small laboratory animals: rats, mouse and golden hamster. 2nd ed. Philadelphia: Saunders BooK Company, 2002.

QUAGGIN, S. E.; VANDEN HEUVEL, G. B.; AND IGARASHI, P. Pod-1, a mesodermspecific basic-helix-loop-helix protein expressed in mesenchymal and glomerular epithelial cells in the developing kidney. Mech. Dev., v. 71, p. 37-48, 1998.

QUAGGIN, S. E.; SCHWARTZ, L.; SHIYING, C.; IGARASHI, P.; DEIMLING, J.; POST, M.; ROSSANT, J. The basic-helix-loop-helix protein Pod-1 is critically important for kidney and lung organogenesis. Development, v. 126, p. 5771-5783, 1999.

RAZA, F. S.; PUDDEFOOT, J. R.; VINSON, G. P. Pref-1, SF-1 and adrenocortical zonation. Endocr. Res., v. 24, p. 977-981, 1998.

RICE, D. A.; MOUW, A. R.; BORGED, A. M.; PARKER, K. L. A shared promoter element regulates the expression of three steroidogenic enzymes. Mol. Endocrinol., v. 5, p. 1552$1561,1991$.

SADOVSKY, Y.; CRAWFORD, P. A.; WOODSON, K. G.; POLISH, J. A.; CLEMENTS, M. A.; TOURTELLOTTE, L. M.; SIMBURGER, K.; MILBRANDT, J. Mice deficient in the orphan receptor steroidogenic factor 1 lack adrenal glands and gonads but express P450 sidechain-cleavage enzyme in the placenta and have normal embryonic serum levels of corticosteroids. Proc. Natl. Acad. Sci. USA, .v. 92, p. 10939-10943, 1995.

SASANO, H.; SHIZAWA, S.; SUZUKI, T.; TAKAYAMA, K.; FUKAYA, T.; MOROHASHI, K.; NAGURA, H. Ad4BP in the human adrenal cortex and its disorders. J. Clin. Endocrinol. Metab., v. 80, p. 2378-2380, 1995.

SUZUKI, T.; KASAHARA, M.; YOSHIOKA, H.; MOROHASHI, K.; UMESONO, K. LXXLL-related motifs in Dax-1 have target specificity for the orphan nuclear receptors Ad4BP/SF-1 and LRH-1. Moll. Cell. Biol., v. 23, p. 238-249, 2003.

SHEN, M.; KAWAMOTO T., TERAMOTO, M.; MAKIHIRA, S.; FUJIMOTO, K.; YAN, W.; NOSHIRO, M.; KATO, Y. Induction of basic helix-loop-helix protein DEC1 (BHLHB2)/Stra13/Sharp2 in response to the cyclic adenosine monophosphate pathway. Eur. J. Cell. Biol., v. 80, p. 329-334, 2002.

SHIMMER, B. P.; WHITE, P. C. Minireview: steroidogenic factor 1 its roles in differentiation, development and disease. Mol. Endocrinol., v. 24, p. 1322-1337, 2010. 
SMITH, L. T.; LIN, M.; BRENA, R. M.; LANG, J. C.; SCHULLER, D. E.; OTTERSON, G. A.; MORRISON, C. D.; SMIRAGLIA, D. J.; PLASS, C. Epigenetic regulation of the tumor suppressor gene TCF21 on 6q23-q24 in lung and head and neck cancer. PNAS, v. 103, p. 982-987, 2006.

TAMURA, M.; KANNO, Y.; CHUMA, S.; SAITO, T.; NAKATSUJI, N. Pod-1/capsulin shows a sex- and stage-dependent expression pattern in the mouse gonad development and represses expression of Ad4BP/SF-1. Mech. Dev., v. 102, p. 135-144, 2001.

TORRES, T. E.; LOTFI, C. F. Distribution of cells expressing Jun and Fos proteins and synthesizing DNA in the córtex of hipophysectomized rats: regulation by ACTH and FGF2. Cell and Tissue research, v. 329, p. 443-455, 2007.

TREMBLEY, J. J.; ROBERT, N. M. Role of nuclear receptors in INSL3 gene transcription in Leydig Cells. Ann. NY. Acad. Sci., v. 1061, p. 183-189, 2005.

VAL, P.; LEFRANÇOIS-MARTINEZ, A-M.; VEYSSIÉRE, G.; MARTINEZ, A. SF-1 a key player in the development and differentiation of steroidogenic tissues. Nucl. Recept., v. 1, p. 8, 2003.

WEISS, D.; STOCKMANN, C.; SCHRÖDTER, K.; RUDACK, C. Protein expression and promoter methylation of the candidate biomarker TCF21 in head and neck squamous cell carcinoma. Oncol. (Dordr.), 2013. [Epub ahead of print]

WHITE, A.; GIBSON, S. ACTH precursors: biological significance and clinical relevance. Clin. Endocrinol. (Oxf.), v. 48, n. 3, p. 251-255, 1998.

WOODSON, K. G.; CRAWFORD, P. A.; SADOVSKY, Y.; MILBRANDT, J. Characterization of the promoter of SF-1, an orphan nuclear receptor required for adrenal and gonadal development. Mol. Endocrinol., v. 11, p. 117-126, 1997.

ZIMMERMANN, S.; SCHWARZLER, A.; BUTH, S.; ENGEL, W.; ADHAM, I. M. Transcription of the Leydig insuline-like gene is mediated by steroidogenic factor-1. Mol. Endocrinol., v. 12, p. 706-713, 1998. 